\title{
Long-term research in Bosque Fray Jorge National Park: Twenty years studying the role of biotic and abiotic factors in a Chilean semiarid scrubland
}

\author{
Investigación de largo plazo en el Parque Nacional Bosque Fray Jorge: Veinte años \\ estudiando el rol de los factores bióticos y abióticos en un matorral chileno semiárido
}

\author{
JULIO R. GUTIÉRREZ1, 2, *, PETER L. MESERVE ${ }^{3}$, DOUGLAS A. KELT ${ }^{4}$, ANDREW ENGILIS JR. ${ }^{4}$, M. ANDREA \\ PREVITALI ${ }^{3}$, W. BRYAN MILSTEAD ${ }^{3,5}$ \& FABIAN M. JAKSIC 6 \\ ${ }^{1}$ Departamento de Biología and Centro de Estudios Avanzados en Zonas Áridas, Universidad de La Serena, Chile \\ ${ }^{2}$ Instituto de Ecología y Biodiversidad, Chile \\ ${ }^{3}$ Department of Biological Sciences, Northern Illinois University, DeKalb, IL 60115, USA \\ ${ }^{4}$ Department of Wildlife, Fish, \& Conservation Biology, University of California, Davis, CA, USA \\ ${ }^{5}$ U.S. Environmental Protection Agency, 27 Tarzwell Drive Narragansett, RI 0288, USA \\ ${ }^{6}$ Center for Advanced Studies in Ecology \& Biodiversity (CASEB), Departamento de Ecología, Pontificia Universidad \\ Católica de Chile, Santiago, Chile \\ ${ }^{*}$ Corresponding author: jgutierr@userena.cl
}

\begin{abstract}
Since 1989, we have conducted a large-scale ecological experiment in semiarid thorn scrub of a national park in north-central Chile. Initially, we focused on the role of biotic interactions including predation, interspecific competition, and herbivory in small mammal and plant components of the community. We utilized a reductionist approach with replicated 0.56 ha fenced grids that selectively excluded vertebrate predators and/or larger small mammal herbivores such as the degu, Octodon degus. Although we detected small transitory effects of predator exclusions on degu survival and numbers, other species failed to show responses. Similarly, interspecific competition (i.e., degus with other small mammals) had no detectable numerical effects (although some behavioral responses occurred), and degu-exclusions had relatively small effects on various plant components. Modeling approaches indicate that abiotic factors play a determining role in the dynamics of principal small mammal species such as $O$. degus and the leaf-eared mouse (Phyllotis darwini). In turn, these are mainly related to aperiodic pulses of higher rainfall (usually during El Niño events) which trigger ephemeral plant growth; a food addition experiment in 1997-2000 verified the importance of precipitation as a determinant of food availability. Since 2004, we have expanded long-term monitoring efforts to other important community components including birds and insects in order to understand effects of abiotic factors on them; we report some of the first results of comprehensive surveys on the former in this region. Finally, we recently shifted focus to documenting effects of exotic lagomorphs in the park. We installed additional treatments selectively excluding small mammals, lagomorphs, or both, from replicated grids in order to evaluate putative herbivore impacts. In conjunction with increased annual rainfall since 2000, we predict that introduced lagomorphs will have increasing impacts in this region, and that more frequent El Niños in conjunction with global climatic change may lead to marked changes in community dynamics. The importance of long-term experimental studies is underscored by the fact that only now after 20 years of work are some patterns becoming evident.
\end{abstract}

Key words: birds, Chilean desert, ephemeral plants, LTER, small mammals.

\section{RESUMEN}

Desde 1989 hemos llevado a cabo un experimento ecológico a gran escala en un matorral espinoso semiárido de un parque nacional en el norte de Chile. Inicialmente, nos centramos en el rol de las interacciones bióticas incluyendo depredación, competencia interespecífica y herbivoría en micromamíferos y componentes vegetales de la comunidad. Usamos una aproximación reduccionista con parcelas replicadas cercadas de 0.56 ha que selectivamente excluían depredadores vertebrados y/o micromamíferos herbívoros más grandes como el degu, Octodon degus. Aunque detectamos efectos transitorios menores en la sobrevivencia y número de degus en las exclusiones de depredadores, otras especies no mostraron respuestas. Similarmente, la competencia interespecífica (i.e., degus con otros micromamíferos) no tenía 
efectos numéricos detectables (aunque ocurrieron algunas respuestas conductuales), y las exclusiones tuvieron efectos relativamente pequeños en varios componentes vegetales. Aproximaciones basadas en modelos indican que los factores abióticos juegan un papel determinante en la dinámica de las especies de micromamíferos principales como O. degus y la laucha orejuda (Phyllotis darwini). En cambio, estos están principalmente relacionados a pulsos no periódicos de lluvias más altas (usualmente durante los eventos El Niño) que gatilla el crecimiento de plantas efímeras; un experimento de adición de alimento en 1997-2000 verificó la importancia de la precipitación como un determinante de la disponibilidad de alimento. Desde el 2004 hemos expandido los esfuerzos de monitoreo de largo plazo a otros componentes comunitarios importantes incluyendo aves e insectos con el fin de entender los efectos de los factores abióticos sobre ellos; informamos algunos de los primeros resultados de censos comprehensivos de aves en esta región. Finalmente, hace poco cambiamos de foco para documentar el efecto de lagomorfos exóticos en el parque. Instalamos tratamientos adicionales excluyendo selectivamente micromamíferos, lagomorfos, o ambos, de parcelas replicadas con el fin de evaluar impactos de herbívoros. En conjunto con el aumento de la precipitación anual desde 2000, predecimos que los lagomorfos introducidos tendrán mayores impactos en esta región y que más frecuentes El Niño en combinación con el cambio climático global puede conducir a cambios marcados en la dinámica comunitaria. La importancia de experimentos de largo plazo es destacado por el hecho que solamente ahora después de 20 años de trabajo algunos patrones están siendo evidentes.

Palabras clave: aves, desierto chileno, LTER, micromamíferos, plantas efímeras.

\section{INTRODUCTION}

The historical debate on the relative importance of biotic interactions such as predation, competition, and herbivory vs. abiotic factors such as climate, has been contentious in population and community ecology (e.g., Nicholson 1933, Andrewartha \& Birch 1954, Sinclair 1989, Turchin 1995, 2003). Although the present consensus is that both biotic and abiotic factors are important, it generally is accepted that biotic factors tend to operate in a density-dependent manner whereas abiotic ones do not. Thus, the former have the potential to regulate population density within a range of dynamic equilibria, whereas the latter may increase population variability outside that range (Sinclair 1989, Turchin 2003).

The emphasis on biotic interactions as a central mechanism controlling populations culminated in the 1980's and 1990's with a call for multifactorial and reductionist approaches to studying field organisms (e.g., Lubchenco 1986, Roughgarden \& Diamond 1986, Schoener 1986). At the same time, greater emphasis was put on ecological scale and the importance of studies over larger spatial and temporal scales (e.g., Wiens 1986, 1989, Wiens et al. 1986, Levin 1992). The issue is not whether any one scale in space or time is «correct,» but rather understanding exactly what is being measured at a particular scale in studying ecological phenomena (Levin 1992). Field manipulations need to be conducted at a scale which adequately distinguishes between changes in local membership and population levels, and those occurring at interhabitat or regional levels (Wiens 1989). Determining the appropriate scale requires an intimate knowledge of organismal biology, including dispersal and long-term population structure. The issue of scale becomes even more crucial when estimating the potential effects of very large-scale processes such as global climate change on smaller scale phenomena such as local and regional biodiversity, biotic interactions, and community structure and energetics (e.g., Risser et al. 1988, Woodmansee 1988, Field et al. 1992, Kareiva et al. 1992, Peters \& Lovejoy 1992, Wessman 1992).

An increasing number of studies have investigated the effects of climatic forces on population dynamics (e.g, Leirs et al. 1997, Forchhammer et al. 1998, Grenfell et al. 1998, Lima et al. 1999a, 1999b, 2001a, 2001b, 2002a, 2002b, 2006, Coulson et al. 2001, Loeuille \& Ghil 2004), and show the joint effects of endogenous and exogenous forces on dynamics of natural populations. Nonetheless, it is clear that in some instances exogenous factors (i.e., climate) are of major importance. For various organisms, feedback structure and climatic forces are key elements to understand numerical fluctuations (Royama 1992, Turchin 1995, Berryman 1999). Further, although linear feedback effects have traditionally been emphasized, nonlinear effects may be the rule rather than the exception (e.g., Stenseth et al. 
1997, Grenfell et al. 1998, Bjørnstad et al. 1998, Berryman 1999, Kristoffersen et al. 2001, Coulson 2004), and they have increasingly been verified (e.g., Sæther et al. 2000, Mysterud et al. 2001, Stenseth et al. 2002, 2004, Ellis \& Post 2004, Lima et al. 2006, Berryman \& Lima 2007).

With evidence increasingly compelling for climatically-induced environmental change, global climatic change (GCC) has become a major focus in ecology. There is no longer doubt that major anthropogenically-induced alterations in organismal distributions, abundance, and dynamics are occurring (e.g., Walther et al. 2002, 2005, Parmesan 2006, Bodkin et al. 2007, IPCC 2007). Increased frequency, duration, and magnitude of El Niño events are one facet of ongoing GCC (Latif et al. 1998, Timmermann et al. 1999, Mann et al. 2000, Diaz et al. 2001, Herbert \& Dixon 2002); although dispute about linkages persists (e.g., Rajagopalan et al. 1997, Kirtman \& Schopf 1998, Kleeman \& Power 2000, Stenseth et al. 2003), GCC may have already altered the El Niño Southern Oscillation (ENSO) phenomenon (Fedorov \& Philander 2000, Kerr 2004, Wara et al. 2005) with current weather patterns reflecting the combination of natural variability and a changing baseline. Several stepwise shifts in climate appear to have occurred in the past 30 years. The eastern Pacific Ocean warmed around 1976 (CLIVAR 1992), and between 1976 and 1998, El Niño events were larger, more persistent and more frequent; the two largest El Niño of the $20^{\text {th }}$ century occurred in this period. In western South America (especially NW Peru and semiarid north-central Chile) increasing rainfall tends to occur during El Niño Southern Oscillation (ENSO) warm phases; low rainfall occurs in other regions such as in Australia and southern Africa. The implications of ENSO-driven changes in precipitation for semiarid regions are multiple (reviews in Jaksic 2001, Holmgren et al. 2006a, 2006b). Elevated rainfall in semiarid Chile leads to dramatic increases in ephemeral plant cover (Dillon \& Rundel 1990, Gutiérrez et al. 1997, Vidiella et al. 1999, Block \& Richter 2000), although it often decreases during succeeding years of multiyear El Niño/high rainfall events, suggesting nutrient limitation (Gutiérrez et al. 1997, de la Maza et al. 2009).
Other groups increase dramatically following El Niño including small mammals (e.g., Jiménez et al. 1992, Meserve et al. 1995, Lima \& Jaksic 1998a, 1998b, 1998c, Lima et al. 2001a, 2001b, 2002a, 2002b, 2006), vertebrate predators (Jaksic et al. 1993, 1997, Arim \& Jaksic 2005, Arim et al. 2006, Farias \& Jaksic 2007), and birds (Jaksic \& Lazo 1999). The responses appear due to upward-cascading effects of rainfall on productivity in regions which normally are arid (Holmgren et al. 2001, 2006a). Similar patterns hold for plant and animal groups where unusually high rainfall occurs during El Niño (e.g., North America, Brown \& Ernest 2002, DeSante et al. 2003) or La Niña years (e.g., Australia, Letnic et al. 2004, 2005). Negative biological consequences of more frequent El Niño/high rainfall events may include the emergence or increased prevalence of certain pathogens as a result of more abundant vectors, reservoirs, and transmission agents (Kovats et al. 1999, Epstein 1999, 2000, Epstein \& Mills 2005). Finally, another negative consequence of GCC and more frequent El Niño events may be a greater impact of introduced species (e.g., Arroyo et al. 2000, Hobbs \& Mooney 2005, Parker et al. 2006, Gutiérrez et al. 2007).

Although many authors have emphasized the need for long-term and manipulative field experiments in ecology (e.g., Likens 1989, Risser 1991, Cody \& Smallwood 1996), to date there are relatively few such studies. We have maintained a field manipulation in a semiarid scrubland in north-central Chile for more than 20 years, making this the longest such study in temperate South America. The emphasis of the study has been modified as incoming data suggested important new directions for research. It began as a study on the relative importance of two forms of biotic interactions (competition vs. predation), but with the onset of the 1991-92 El Niño event, the overwhelming importance of abiotic factors on this semiarid system became clear. We have now tracked small mammals and plants through multiple El Niño/high rainfall periods, with similar (albeit not identical) biotic responses. Recent studies on seed consumption, however, have underscored the importance of birds (Kelt et al. 2004a, 2004b, 2004c), and observations have indicated that they also are strongly influenced by both 
abiotic and biotic influences, and possibly by our field manipulations as well.

The history of population and community ecology has shown that single factor or simplistic explanations for major phenomena often fail to endure. In community ecology, studies that emphasize multiple biotic interactions and both indirect and direct effects have become increasingly important (e.g., Strauss 1991, Menge 1995, Abrams et al. 1996). Notable examples are studies of herbivore and/or granivore interactions with plants and/or seeds (e.g., McNaughton 1976, Brown et al. 1986, Brown \& Heske 1990, Brown 1998), inter-guild interactions and plants and/or seeds (e.g., Davidson et al. 1984, 1985, Brown et al. 1986, Guo et al. 1995, Ostfeld et al. 1996, Brown 1998), and effects of predators on prey and the role of food (e.g., Taitt \& Krebs 1983, Desy \& Batzli 1989, Krebs et al. 1995).

We have argued that ecological dynamics at our site shift between "top-down" and "bottom-up" control with important roles for both biotic and abiotic factors (Meserve et al. 2003). This may be possible in part because this region is a highly variable semiarid environment. Whereas the role of biotic interactions may receive more attention because of tractability for manipulation, our work shows that abiotic factors also are very important in this system, and deserve more attention in ecological studies generally (Dunson \& Travis 1991, Karr 1992). Our study is helping to clarify the important role of such abiotic factors when superimposed on a suite of biotic interactions; it is largely the long-term baseline that our study affords that provides us with insights into the relative roles of these influences.

Work at our site provides important baseline data for interpreting long-term changes in semiarid Chile but has important implications for other arid and semiarid systems. Over the last 1,000 years, rainfall in northern Chile has declined within a more gradual aridity trend (Bahre 1979, Villalba 1994). Rainfall in the park averaged $209 \mathrm{~mm}$ year ${ }^{-1}$ in 1940-49, $185 \mathrm{~mm}$ in 1960-69, $127 \mathrm{~mm}$ in $1970-79,85 \mathrm{~mm}$ in $1980-89$, and $113 \mathrm{~mm}$ in 1990-99 (Kummerow 1966, Fulk 1975, Gutiérrez 2001). Although there has been little change in small mammal assemblage and shrub cover at Fray Jorge over 50 years, El Niño-related outbreaks of small mammals and effects on agriculture have become more dramatic elsewhere (e.g., Pearson 1975, Péfaur et al. 1979, Fuentes \& Campusano 1985, Jiménez et al. 1992, Jaksic \& Lima 2003). The surrounding north-central semiarid region ("Norte Chico") has become highly desertified (Bahre 1979, Schofield \& Bucher 1986), with $44 \%$ of ca. 3.5 million ha of the IV Region (within the Norte Chico) characterized as "sterile" by the mid-1970s due to overgrazing, overcutting, and neglect (Ovalle et al. 1993). Desertification has occurred at a rate of about 0.4-1.4 \% year-1 (Bahre 1979); by the early 1990's, less than $0.1 \%$ of the Norte Chico was cultivated, and unrestricted grazing and fuelwood collection continued in the predominantly rural areas (Ovalle et al. 1993). Interestingly, El Niño events may offer opportunities for restoration of such systems (Holmgren \& Scheffer 2001). However, until recently, little was known about the dynamics of plant-animal interactions here (but see Armesto et al. 1993, Gutiérrez 1993, 2001, Ovalle et al. 1993, Whitford 1993). Consequently, northern Chile and this study in particular, provide important sources of baseline data for ecologists as well as conservation and restoration biologists.

\section{STUDY AREA AND METHODOLOGY}

In 1989, we began a large-scale manipulation in Bosque Fray Jorge National Park $\left(71^{\circ} 40^{\prime} \mathrm{W}\right.$, $30^{\circ} 38^{\prime}$ S; Fray Jorge hereafter), a 10,000 ha Biosphere Reserve in the north-central Chilean semiarid zone. The park contains semiarid thorn scrub vegetation and remnant fog forests that have been protected from grazing and disturbance since 1941 (Squeo et al. 2004). The thorn scrub includes spiny drought-deciduous and evergreen shrubs and understory herbs on a primarily sandy substrate (Muñoz \& Pisano 1947, Muñoz 1985, Hoffmann 1989, Gutiérrez et al. 1993a). The climate is semiarid Mediterranean with $90 \%$ of the mean annual $133 \mathrm{~mm}$ (average between 1989 and 2008) precipitation falling in winter months (MaySept.), and warm, dry summers. Since 1989, there have been five El Niño/high rainfall events in this region: 1991-92 (233-229 $\mathrm{mm})$, 
1997 (330 mm), 2000-2002 (236-339 mm), 2004 (168 $\mathrm{mm})$, and 2006 (147 $\mathrm{mm})$; intervening years have been dry (11 to $89 \mathrm{~mm}$ ).

Based on earlier work (e.g., Meserve 1981a, 1981b, Meserve et al. 1983, 1984, 1987, Meserve \& Le Boulengé 1987), we initially focused our attention on the role of biotic interactions in the community, specifically, vertebrate predation, small mammal herbivory, and interspecific competition among small mammals. Much of our earlier interest has been on the biology of an important herbivore, Octodon degus (Molina, 1782) (degu), a medium-sized (ca. 120-150 g) caviomorph rodent characteristic of Mediterranean Chile; Fray Jorge is near the northern limits of the degu's range. Other small mammals include the uncommon Abrocoma bennetti Waterhouse, 1837 (150-250 g) and several smaller (20-80 g) omnivorous to granivorous/insectivorous species such as Abrothrix olivaceus (Waterhouse, 1837), A. longipilis (Waterhouse, 1837), Phyllotis darwini (Waterhouse, 1837), Oligoryzomys longicaudatus (Bennett, 1832), and Thylamys elegans (Waterhouse, 1839) (Meserve 1981a, 1981b). Principal small mammal predators include owls (Tyto alba [Scopoli, 1769], Athene cunicularia [Molina, 1782], Bubo magellanicus [Lesson, 1828], Glaucidium nanum [King, 1828]) and the culpeo fox (Lycalopex culpaeus [Molina, 1782]; Fulk 1976a, Jaksic et al. 1981, 1992, 1993, 1997, Meserve et al. 1987, Salvatori et al. 1999). Other predators are snakes (Philodryas chamissonis [Wiegmann, 1835]) and a large teiid lizard (Callopistes maculatus Gravenhorst, 1838; Minn 2002, Jaksic et al. 2004). Numbers of predators are unusually high because the park contains the largest remaining intact scrub habitat in north-central Chile (Bahre 1979).

The initial experimental complex consisted of 16 small mammal live-trapping grids (75 x $75 \mathrm{~m}=0.56 \mathrm{ha})$ in thorn scrub habitat in an interior valley of the park ("Quebrada de las Vacas," $240 \mathrm{~m}$ elev.; "central grid complex" in Fig. 1) previously studied by Fulk (1975, 1976a, 1976b), Meserve (1981a, 1981b), and Meserve \& Le Boulengé (1987). The original design included four treatments each with four randomly assigned grids: 1 ) controls, with low $(1.0 \mathrm{~m} \mathrm{~h}) 2.5 \mathrm{~cm}$ mesh fencing buried ca. 40 $\mathrm{cm}$ with $5 \mathrm{~cm}$ d holes at ground level to provide access by all small mammals and predators $(+\mathrm{D}+\mathrm{P})$; 2$)$ predator exclusions, with tall $(1.8 \mathrm{~m} \mathrm{~h}) 5 \mathrm{~cm}$ mesh fencing buried $40 \mathrm{~cm}, 1 \mathrm{~m}$ overhangs, and polyethylene mesh $(15 \mathrm{~cm})$ netting overhead, excluding predators but allowing small mammal access (including degus; +D -P); 3) degu exclusions, with low $(1.0 \mathrm{~m} \mathrm{~h}) 2.5 \mathrm{~cm}$ mesh fencing without holes to exclude degus but not other small mammals or predators $(-\mathrm{D}+\mathrm{P})$; or 4$)$ degu \& predator exclusions, with tall $(1.8 \mathrm{~m} \mathrm{~h}) 5 \mathrm{~cm}$ mesh fencing, with high overhangs, and netting to exclude predators, supplemented with $2.5 \mathrm{~cm}$ fencing to exclude degus (-D -P). Our manipulations have utilized a long-term "press" approach (sensu Bender et al. 1984) to examine these biotic interactions. Sampling methods are as follows (see also Meserve et al. 1993a, 1993b, 1995, 1996, Gutiérrez et al. 1993a, 1993b, 1997, Jaksic et al. 1993, 1997): 1) Small mammals are trapped for four days/ month/grid (5 x 5 stations, $15 \mathrm{~m}$ interval, two traps/station). We estimate population size with minimum number known alive (MNKA; Hilborn et al. 1976). 2) Perennial shrub cover is measured every three month with four permanent $75 \mathrm{~m}$ parallel transects/grid and point intercept method (0.5 $\mathrm{m}$ intervals). 3) Ephemeral (annuals + geophytes) cover is measured monthly in the growing season (April-Aug. to Oct.-Dec.) on 10 random $1.5 \mathrm{~m}$ segments subdivided into 30 points $(5 \mathrm{~cm}$ intervals) on the transects. 4) Soil samples ( $\mathrm{n}=$ 20 random samples $[3 \mathrm{~cm} \mathrm{~d} \mathrm{x} 5 \mathrm{~cm}$ depth $=$ $35.35 \mathrm{~cm}^{3}$ ] grid $^{-1}$ ) are collected every four month. 5) Fox scats and owl pellets are collected monthly from the site and nearby roosts; predators are monitored monthly with sightings and olfactory lines.

We have employed various approaches to data analysis. Initially, we used repeated measures analysis of variance (rmANOVA, PROC GLM; SAS 1990a, 1990b, Potvin et al. 1990, von Ende 2001), and mixed model rmANOVA (PROC MIXED; Wolfinger \& Chang 1995, SAS 1996). Small mammal survivorship was analyzed with PROC LIFETEST (SAS 1990b) and nonparametric log-rank tests (Lee 1980, Fox 2001). Results of analyses on small mammals and predators were reported in Jaksic et al. (1993, 1997), Meserve et al. (1993a, 1993b, 1995, 1996, 1999, 2001, 2003), and Milstead (2000). 
Recently (Previtali 2006) we investigated the effects of predator/competitor exclusions using Log Response Ratios (LRRs), calculated as the $\log$ of the ratio of the density of the target species in the competitor or predator exclusion treatment over its density in the control $\left(\mathrm{LRR}=\mathrm{Ln}\left(\mathrm{N}_{\mathrm{t}}\right.\right.$ exclusion $/ \mathrm{N}_{\mathrm{t}}$ control); Schmitz et al. 2000, Berlow et al. 2004). We assumed that biotic interactions (competition, predation) would vary depending on the duration of wet or dry phases since this relates directly to resource availability. Consequently, we categorized each year based on whether wet vs. dry conditions (i.e., above- or belowaverage rainfall, respectively) prevailed in that year and the preceding year. Thus, we defined each year as part of a Dry-Dry, Dry-Wet, WetWet, or Wet-Dry phase. Given the lag in demographic responses to resource availability, we posited that Dry-Wet years would have high resource availability (the wet year) but low population densities (due to the preceding dry year). Similarly, Wet-Dry years should have low resources (current, dry year) but high population densities (in response to the preceding wet year), and so on.

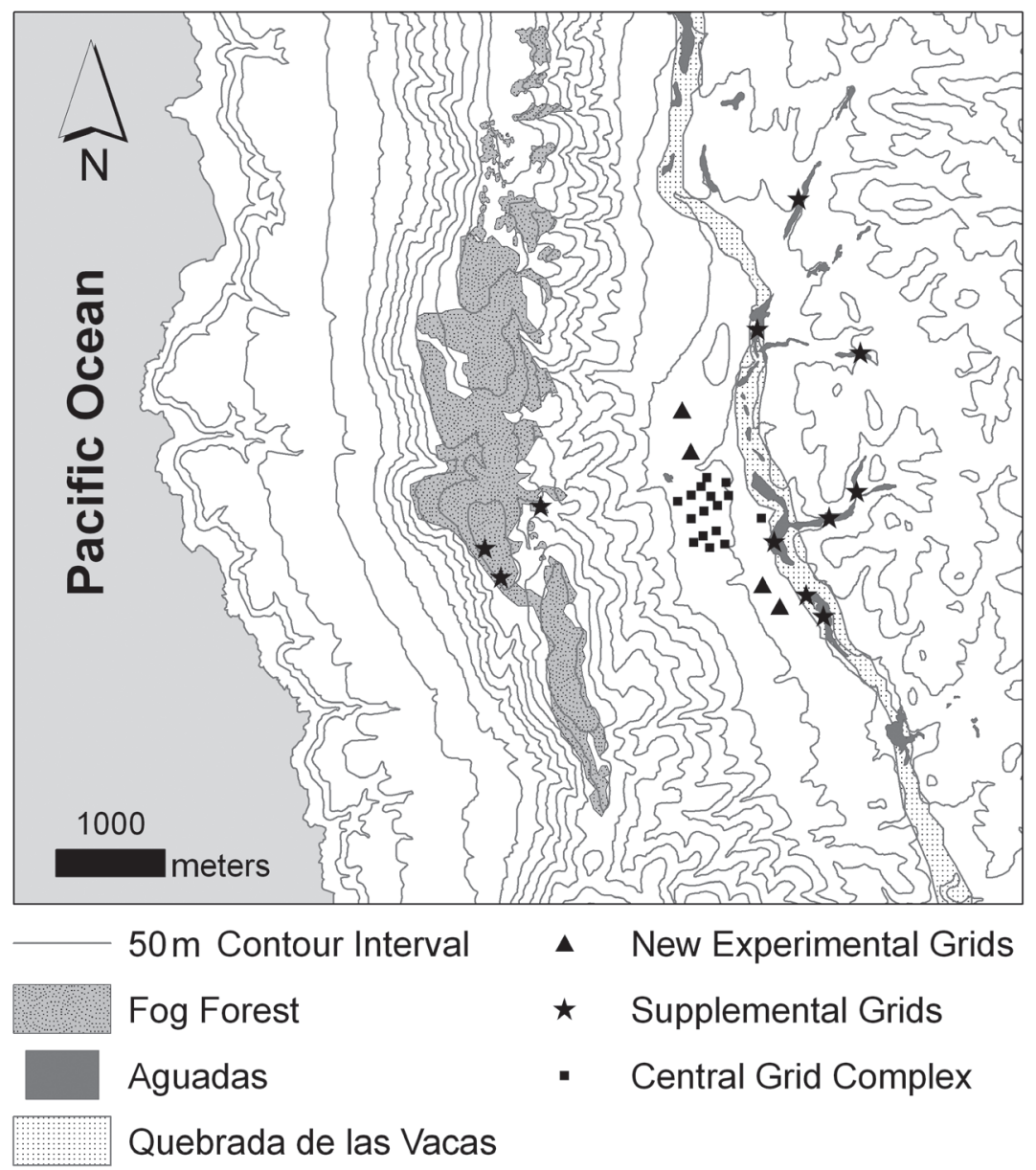

Fig. 1: Location of study area, grids and major habitats in Fray Jorge. Light shaded areas are predominantly thorn scrub habitat. Sixteen grids in the "central grid complex" have been used since 1989; "supplemental grids" located in other habitats (i.e., fog forest, aguadas + quebradas) were sampled during 1996-2003. "New experimental grids" were added in 2007-2008 and target lagomorphs with and without small mammal exclusions.

Ubicación del área de estudio, parcelas y hábitats principales en Fray Jorge. Áreas con sombreado claro son predominantemente hábitat de arbustos espinosos. Desde 1989 se han usado dieciséis parcelas en el "complejo de parcelas centrales"; "parcelas adicionales" ubicadas en otros hábitats (i.e., bosque de neblinas, aguadas + quebradas) se muestrearon durante 1996-2003. "Parcelas experimentales nuevas" se agregaron en 2007-2008 con exclusiones de lagomorfos y micromamíferos. 
We assessed behavioral (foraging) responses to predator removal with "giving up densities" from foraging trays (Yunger et al. 2002, Kelt et al. 2004a, 2004b, 2004c). This allowed us to evaluate whether experimental treatments have had functional effects of small mammal foraging independent of their numerical responses to manipulation of predator and/or interspecific competition.

For plant responses, we estimated cover (angular transformed) and seed densities (logtransformed) and used annual peak values (due to varying length of the annual growing season) to allow balanced between-year analyses with rmANOVA (Gutiérrez et al. 1997). Elsewhere we compared plant densities and biomass across our experimental treatments (log-transformed; Gutiérrez \& Meserve 2000).

Prior to manipulations we documented no significant between-treatment differences (small mammals: pre-test period = March-May 1989; plants: 1989). Plant nomenclature follows Marticorena \& Quezada (1985).

\section{RESULTS AND DISCUSSION}

\section{Effects of predation on small mammals}

O. degus responded positively to predator exclusions (Previtali 2006), with greater LRRs during prolonged droughts (i.e., Dry-Dry years, 1994-1996, and 1999; Fig. 2). Other

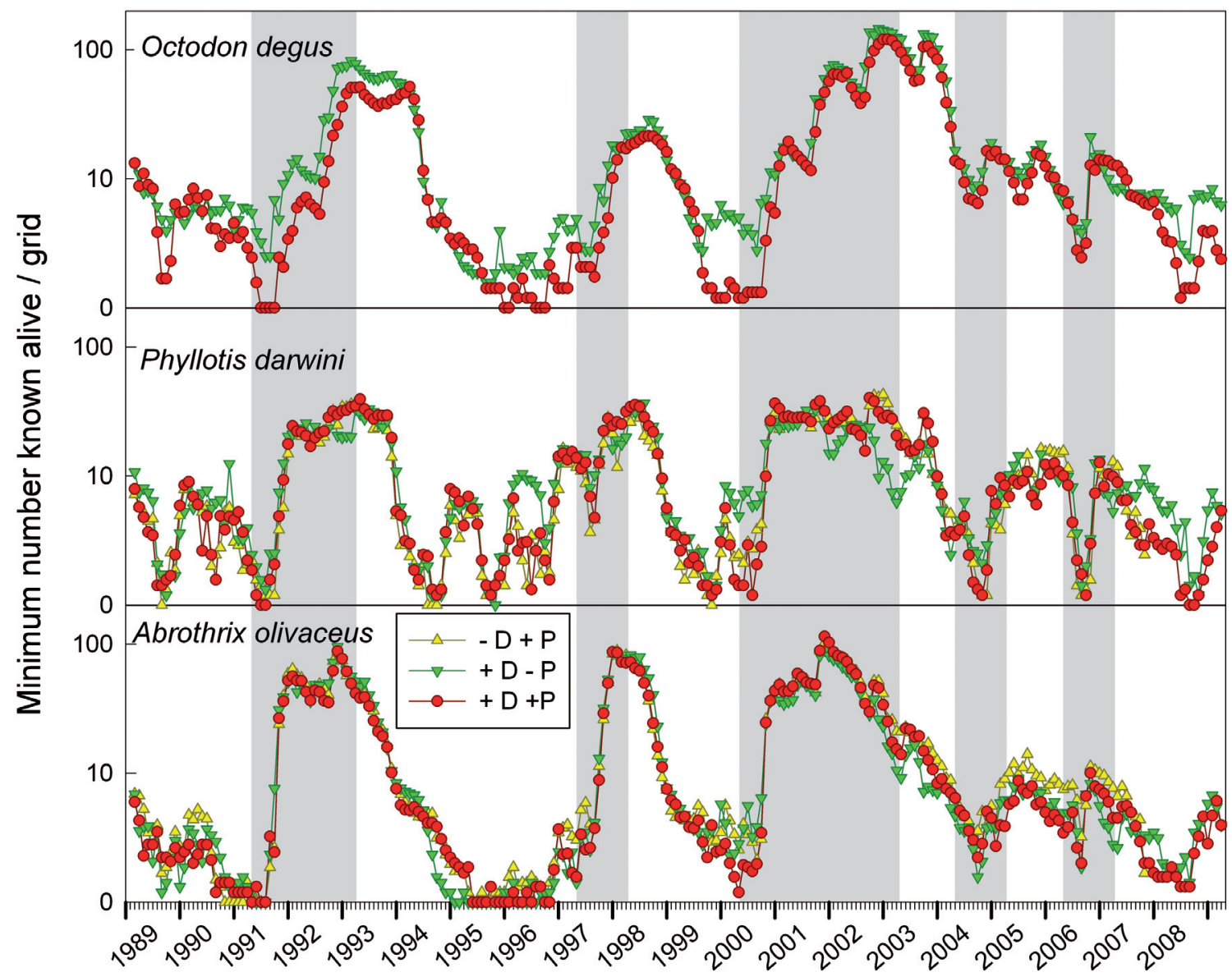

Fig. 2: Population trends for three small mammals in Fray Jorge during 1989-2007. Treatments indicated by symbols and letters $(+/-\mathrm{D}=$ presence or absence of degus; $+/-\mathrm{P}=$ presence or absence of predators).

Tendencias poblacionales de tres micromamíferos en Fray Jorge durante 1989-2007. Los tratamientos están indicados por símbolos y letras $(+/-\mathrm{D}=$ presencia o ausencia de degus; +/-P= presencia $\mathrm{o}$ ausencia de depredadores). 
species (Phyllotis and A. olivaceus) showed only slight or even negative effects of predator exclusion. Degu survival probabilities were significantly greater on exclusions than control grids (Previtali 2006). Although we have documented behavioral changes in Octodon and other species under predator exclusion conditions (Lagos 1993, Lagos et al. 1995, Yunger et al. 2002, 2007, Kelt et al. 2004a), these often are not manifested in numerical responses to predation.

\section{Predator numbers and diets}

Both owl and fox diets are dominated by $O$. degus, Phyllotis, and Abrocoma (Jaksic et al. 1993, 1997, Silva et al. 1995). Predators showed numerical responses to changes in prey abundance, with increases after El Niño events and declines as prey decreased (Jaksic et al. 1997, Salvatori et al. 1999). Foxes and some owls were more omnivorous at low small mammal levels with increased importance of insects (G. nanum, A. cunicularia: Silva et al. 1995) and seeds + fruits (L. culpaeus: Castro et al. 1994).

\section{Effects of competition by Octodon on other small mammals}

Octodon negatively impact trophicallydissimilar species such as A. olivaceus (Meserve et al. 1996, Yunger et al. 2002, Kelt et al. 2004a, Previtali 2006), Oligoryzomys (Milstead 2000), and Thylamys (Meserve et al. 2001). Surprisingly, degus may have a facilitative influence on Phyllotis; this species exhibited higher densities in controls than degu exclusions.

\section{Effects of herbivores and predators on plants}

Vegetative responses to herbivore (i.e., degus) and/or predator exclusions have been heterogeneous (Gutiérrez et al. 1997, Gutiérrez \& Meserve 2000). Perennial cover showed no significant treatment responses, but diversity increased on degu exclusions. Some species showed greater cover in plots excluding degus (i.e., Baccharis paniculata DC., Chenopodium petiolare H.B.K.) or predators (i.e., Proustia cuneifolia D. Don). Chenopodium petiolare is a suffructicose perennial and an important degu food (Meserve 1981b, 1983, 1984). Ephemerals (annuals + geophytes) showed no significant main treatment effects on cover or diversity, but total biomass was significantly higher in plots accessible to degus and predators (Gutiérrez \& Meserve 2000). Overall, consumptive effects of degus were relatively small, whereas their indirect activities appeared to increase ephemeral biomass. Seed densities of annual species, including those of Erodium and Moscharia pinnatifida R. et P., were higher in degu-access grids (Gutiérrez et al. 1997). Widespread, adventitious herbs (e.g., Erodium) may be facilitated by disturbance due to runway development and activity as well as digging under bushes.

Thus, degus appear to exert complex effects including both depression and facilitation of plants and seeds. However, the effects of other rodents (most notably Phyllotis and A. olivaceus, which comprised $74.8 \%$ of individuals captured of the three most common species) could not be separated from those of degus, suggesting density or energetic compensation (re Ernest \& Brown 2001a, 2001b). Given this limitation, in 2001 we converted four former degu \& predator exclosures (-D -P) to all-small mammal exclosures (-SM) by removing the original netting and fencing, and installing $1.5 \mathrm{~m} \mathrm{~h} 0.25$ inch hardware cloth fencing topped with ca. 20 $\mathrm{cm}$ metal flashing. These plots were selected because they had shown the least vegetative changes in over $12 \mathrm{yrs}$. Trapping procedures remained identical, but captured animals were marked and then released $\sim 1 \mathrm{~km}$ away. Although not completely effective, all-small mammal exclusions have reduced most species to $23.4 \pm 9.8 \%( \pm \mathrm{SE})$ of control populations since 2002 . Some plants responded immediately and dramatically. In the first year of these treatments, cover by Plantago hispidula $\mathrm{R}$. et $\mathrm{P}$. increased to ca. four times that in control grids. Although this species is an important food of herbivorous rodents in the study area (Meserve 1981b), seed densities were similar in $-\mathrm{SM}$ and control treatments. Consequently, the best explanation for the increase of $P$. hispidula here and not in degu exclusion grids was absence of herbivory by non-degu species, most likely the herbivorous Phyllotis. However, this difference 
in cover was not maintained in subsequent years, so the general importance of this effect is not clear to us. Another immediate response was that Adesmia bedwellii Skottsb., a perennial shrub comprising $~ 8 \%$ of shrub cover at our study site, produced significantly more new leaves and buds in -SM plots. Other shrubs (e.g., Porlieria, Proustia) have not shown these responses, indicating that small mammal impacts on perennial shrub species were selective. Overall, effects of excluding native small mammals have been relatively small. We currently are investigating other aspects such as plant community responses to rainfall events (Gaxiola et al. unpublished data). Using a 20-year datastream on annual plants and climatic factors at Fray Jorge, Gaxiola et al. (unpublished data) documented that annual plant cover (a proxy of productivity) was strongly enhanced by community evenness but not by species richness. Years with $>100 \mathrm{~mm}$ rainfall led to linear increases in community evenness, whereas species richness saturated by 100 $\mathrm{mm}$. Annual rainfall and species richness exerted strong indirect effects on annual plant cover via community evenness. These authors concluded that community evenness is relevant for explaining climate-driven changes in productivity of semiarid areas, where increased variability in rainfall is predicted by global climate models.

\section{Effects of ENSO on small mammals and plants}

Our initial field design assumed a central ecological role of biotic interaction. However, it is apparent that understanding the impact of abiotic factors is fundamental to interpreting long-term trends. The five El Niño/high rainfall events recorded since 1989 (shaded in Fig. 2) are natural "pulse" experiments that trigger large increases in plant and small mammal populations and thus, alter the role of biotic vs. abiotic factors in the community. Data from control grids provide insights to organismal responses to these events (Meserve et al. 1995, 1999, 2003, Gutiérrez et al. 1997, 2000a, 2000b, Gutiérrez \& Meserve 2000, Previtali 2006). For example, of 401,861 captures of 69,029 individuals of 10 small mammal species on all grids through April 2009, $23.5 \%$ and $24.1 \%$, respectively, have been on controls. Of these, $56.4 \%$ and $65.7 \%$ (captures and individuals, respectively) have occurred during high rainfall periods comprising only $39.7 \%$ of the 242 month of study. Although responses of small mammal species to rainfall events differ in timing, they are similar in being 2-3 orders of magnitude in both numbers and biomass (Meserve et al. 2003), which contrasts strongly with patterns for North American arid/semiarid systems where relative stability in numbers and biomass of small mammals over time suggests homeostasis (Ernest \& Brown 2001a).

Spatial dynamics are pivotal to understanding patterns in our system (Meserve et al. 1999, Milstead 2000, Milstead et al. 2007). In thorn scrub, O. degus, Phyllotis, and Thylamys are resident "core" species that occur in all surveys. A. olivaceus is a "quasicore" species, almost always present but with explosive increases after high rainfall years. “Opportunistic species” (e.g., Oligoryzomys, A. longipilis) disappear from thorn scrub during drought periods but persist in peripheral habitats such as "aguadas" and quebradas (areas with mesic vegetation and/or standing/ subsurface water) and fog forest on coastal ridges ("supplemental grids" Fig. 1). Milstead (2000) verified haplotypic variation among some taxa such as Phyllotis and Oligoryzomys in different habitats within the park, suggesting spatial isolation at a rather small scale, at least during dry periods.

Plants also have shown heterogeneous, and in some cases dramatic, responses to ENSO/ high rainfall events (Gutiérrez et al. 1997, 2000a, 2000b, Gutiérrez \& Meserve 2003; Fig. 3 ). Perennial cover only varied from $48.5 \%$ to $64.4 \%$ in 20 years, similar to values of 50 and 35 years ago (Muñoz \& Pisano 1947, Meserve 1981a, Gutiérrez et al. 1993a). In contrast, ephemeral cover varied from $0 \%$ during a $\mathrm{La}$ Niña event (1998, $11 \mathrm{~mm}$ ppt.) to $80-86 \%$ during El Niño/high rainfall years (1991, 1997, 2002). Decreases during ensuing years of multiyear high rainfall events (i.e., 1992, 200102) suggest nutrient depletion (Gutiérrez et al. 1993b, 1997). Maximum seed densities reached $41,832 \mathrm{~m}^{-2}$, similar to North American deserts (Inouye 1991), but they do not track rainfall as closely as does ephemeral cover (Gutiérrez \& Meserve 2003). Similar responses have been documented elsewhere in 
semiarid Chile (Dillon \& Rundel 1990, Gutiérrez et al. 2000a).

In summary, we have documented some biotic responses to predation, competition, and herbivory, but interactions vary among species and over time. Predation appears to affect numbers and survival of some core species, but has weak or no effects on opportunistic ones. Interspecific competition generally appears weak among small mammals although there is evidence for behavioral interactions. Herbivore effects are heterogeneous, with both negative and positive responses to degu exclusions as well as some indirect (positive) effects of predators. In contrast, responses of both plants and animals to abiotic factors related to $\mathrm{El} \mathrm{Niño/high} \mathrm{rainfall} \mathrm{events} \mathrm{are}$ dramatic, implicating the importance of pulsed resources (e.g., Ostfeld \& Keesing 2000, Stapp $\&$ Polis 2003); similar responses have been documented in North American deserts (Valone \& Brown 1996), but these studies contrast markedly with ours in documenting strong effects of small mammal granivores in North America (e.g., Brown et al. 1986, Brown \& Heske 1990a, 1990b; Curtin et al. 2000) or a relatively minor role for precipitation vs. biotic interactions there (Ernest et al. 2000, Brown \& Ernest 2002).

\section{ON-GOING STUDIES}

Ongoing studies at our site have developed as data allowed us to refine or refocus our attention. As noted above, we initially argued for a "shifting control" view of the relative importance of various biotic and abiotic factors in this system (Meserve et al. 1999, 2001, 2003, Gutiérrez et al. 2000b). However, Previtali (2006) showed that the top-down influence of predators had strongest effects primarily when prey numbers were low near the end of prolonged droughts; data from Aucó, roughly $115 \mathrm{~km} \mathrm{SSE}$ of Fray Jorge, also implicated predation in density-dependent dynamics of Phyllotis (Lima et al. 2001a, 2002a, 2002b). However, at least at Fray Jorge neither predators nor herbivores appear to "control" their respective resources. Although transitory and variable effects of predators and herbivores can be demonstrated on some

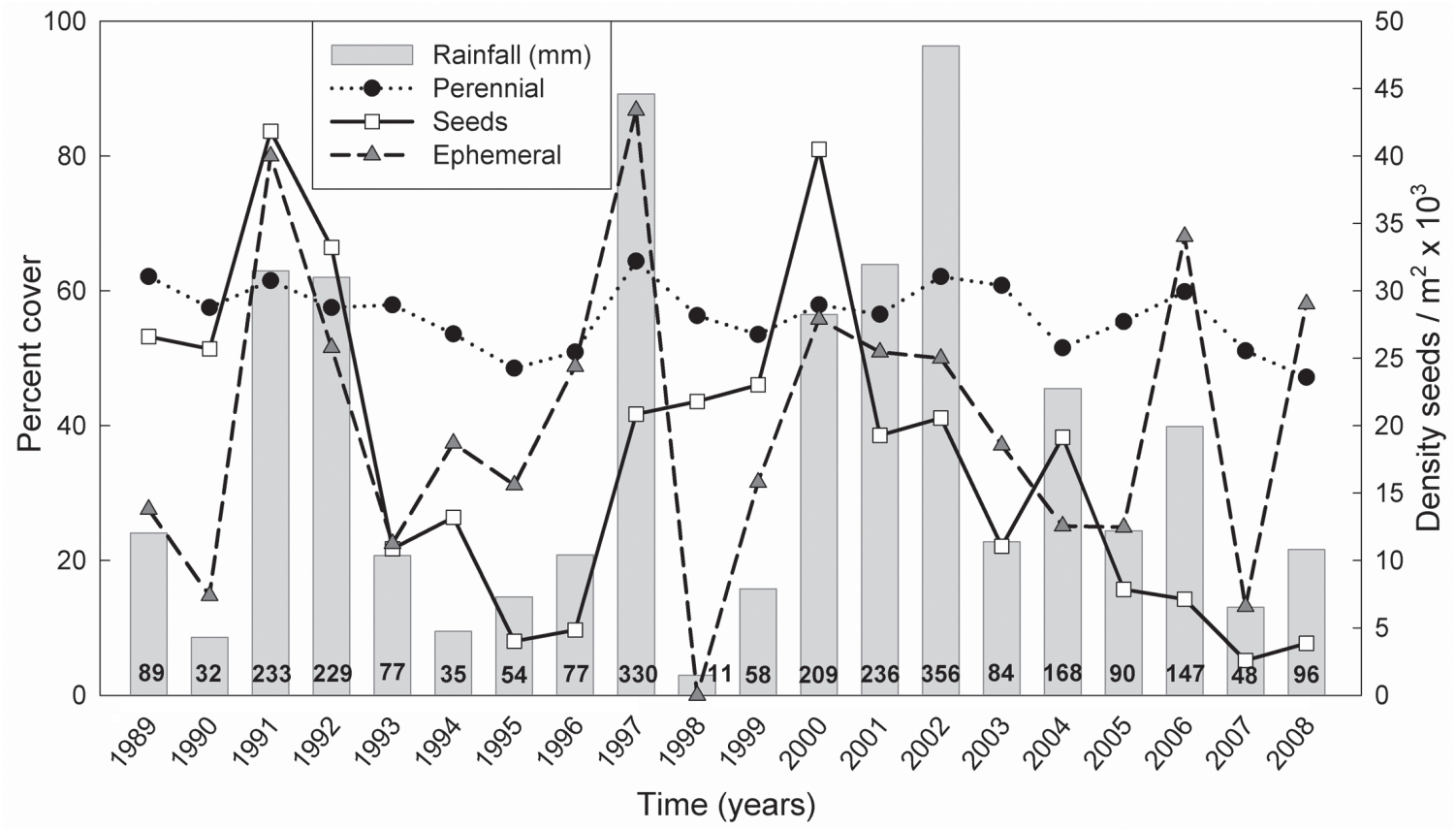

Fig. 3: Annual peak plant cover, seed densities, and total rainfall for control grids $(+\mathrm{D}+\mathrm{P})$ for 19 years during 1989-2008.

Cobertura máxima anual de plantas, densidad de semillas y lluvia total en las parcelas control (+D+P) para 19 años durante 1989-2008. 
components of the community, it is increasingly clear that "bottom-up" factors -rainfall and nutrients for plants, food for small mammals and their predators- are the dominant drivers at our study site (see also Karr 1992, Polis et al. 1997, Polis 1999, Holmgren et al. 2001). The transition between El Niño and non-El Niño years is abrupt; "bottom-up" control appears to prevail generally, interrupted by brief periods of "topdown" effects; even the regulatory nature of such top-down influences, however, remains unclear in the light of recent demographic modeling (Previtali 2006, Previtali et al. 2009, see below). Thus, there may be a productivity threshold above which we see a covarying relationship between consumer and resource abundances (Oksanen et al. 1981, McQueen et al. 1986, 1989, Mittelbach et al. 1988, Oksanen \& Oksanen 2000).

Experimental food addition positively affected numbers and biomass of most core/ quasi-core species (i.e., O. degus, Phyllotis, A. olivaceus) during dry periods, but not during El Niño/high rainfall periods (Meserve et al. 2001). Within the context of a 3-trophic level system (vegetation, rodents, predators), food limitation implies density-dependence resulting in strong oscillations (Turchin \& Batzli 2001). Further, a relationship between productivity and food chain length has been implicated at Aucó (Arim \& Jaksic 2005, Arim et al. 2007), which has a similar small mammal and predator assemblage. Thus, predators may be responding to rainfall and productivity indirectly; prey abundance and functional responses among predators also are involved (Farias \& Jaksic 2005).

Additionally, spatial dynamics are important in understanding population and community processes in this system (Milstead 2000, Milstead et al. 2007), possibly including source-sink dynamics (sensu Pulliam 1988, Watkinson \& Sutherland 1995, Dias 1996). Spatial factors are known to be important in small mammal population cycles (Lidicker 1991, 1995) but, unlike arvicoline population cycles, oscillations at our site seem more affected by extrinsic (abiotic) factors rather than intrinsic regulation.

Given these observations and the overall complexities of this system, we have recently adjusted our focus to include three other areas of research in Fray Jorge. In combination with long-term monitoring, these will allow us to better identify the importance of key components as well as address heretofore unexamined questions.

\section{1) Modeling small mammal population dyna- mics}

We recently applied demographic modeling to provide deeper insight to our long-term small mammal data set (Previtali 2006). Our database is unique in extending over three trophic levels (plants-rodents-predators), spanning several El Niño/high rainfall events, and combining both observational and experimental approaches. Given the remarkable fluctuations that small mammal populations at Fray Jorge have undergone over 20 years, and the general agreement that both endogenous and exogenous factors are important in explaining population structure and change, a basic question is: What is the relative role of endogenous (feedback structure) vs. exogenous (ENSO-driven rainfall) factors in determining small mammal numerical fluctuations?

We have documented important features in common among the population dynamics of the three small mammal species analyzed to date - O. degus, Phyllotis, and A. olivaceus. Population changes of the latter two species were driven by the combined effect of both intrinsic (density dependent) and extrinsic (climatic) factors (Lima et al. 2006), more especifically by intraspecific competition and current and lagged rainfall. However, climate influenced dynamics for these species through very different mechanisms. Whereas rainfall had a simple additive effect for A. olivaceus, the best model for population growth of Phyllotis was a version of the Ricker model, with rainfall influencing carrying capacity nonadditively, acting as the denominator in the ratio with population size (Lima et al. 2006).

Recently we applied more descriptive parameters (e.g., predation and food resources) to model variation in the population rate of change of Phyllotis and O. degus (Previtali et al. 2009). Dynamics of both species were driven by a non-additive interaction of intraspecific competition and resource availability consistent with earlier 
predictions (Lima et al. 2006). However, resource availability was better represented by the combined effect of seed density and plant cover for Phyllotis, and by rainfall for O. degus (Previtali et al. 2009). Although earlier work suggested influences of predation on $O$. degus (e.g., Lagos 1993, Lagos et al. 1995, Meserve et al. 1993b, 1996), the longer time series analyzed indicated that predation is not a key driver of population dynamics of degus or Phyllotis. Thus, bottom-up forces had strong impacts on these two species. For both, the per capita population growth rate was negatively associated with the ratio of population density over current resources, and provided the greatest explanatory power for this variable (Previtali et al. 2009). A secondary influence was the additive lagged effect of the previous year's resource availability.

In summary, the dynamics of three dominant small mammal species at our site $(A$. olivaceus, Phyllotis, and $O$. degus) are driven by climate-mediated variation in resources, and this leads to three new questions that we are addressing with these data. First, what are the underlying mechanisms? Second, what will be the dynamical consequences of altered rainfall patterns caused by GCC? Third, are species similarly influenced by climatically-mediated resource availability and are the general patterns similar to those documented already?

We also are expanding the analysis to examine aspects of these dynamics at shorter time intervals; rather than a single observation per year, we are investigating patterns associated with intra-annual variation in resources. This finer scale will provide insights to processes occurring at shorter time scales, while enabling us to obtain a more accurate estimate of lags in population responses to endogenous and exogenous factors (cf., Lewellen \& Vessey [1998]).

We are appling stochastic stage-structured models to $O$. degus to make predictions of prospective trends in the population rate of change. We incorporate stochasticity to these models as variation in annual precipitation, reflecting predicted increases in mean and variance of annual rainfall in response to GCC (more frequent El Niño events, occasionally strong La Niña events). We are developing models using the mean and variance of demographic parameters (survival and fecundity) estimated from 18 years of data (through 2006; Previtali et al. 2010), and are validating the models by comparing predicted population size with those observed since 2006. This approach has been used to understand the effects of climatic variation on the dynamics of Peromyscus maniculatus (Reed et al. 2007).

We look forward to applying similar quantitative approaches to other species in the assemblage, in particular Thylamys and $A$. longipilis, insectivorous species with very different dynamics (Meserve et al. 1995, 2003). The former is a "core species" but exhibits strong intra-annual fluctuations, whereas the latter is an "opportunistic species" that disappears from the thorn scrub during dry periods but maintains populations in the fog forests and immigrates to the thorn scrub during El Niño/high-rainfall events. Whereas climate and food availability have been implicated as important demographic drivers in Thylamys (Lima et al. 2001b), those of $A$. longipilis appear dominated by higher-order processes, at least in southern Chile (Murúa et al. 2003). The pattern of fluctuations observed for A. longipilis at Fray Jorge, with slow increases after rainy years followed by slow declines, is typical of second-order dynamics, although influences from cyclic external factors (e.g., oscillating climatic forces) can generate apparent second-order patterns in a first-order dynamics (Berryman \& Lima 2007). We are investigating dynamics of $A$. longipilis using approaches similar to those recently applied to other species in Fray Jorge (Previtali et al. 2009), involving time series analyses to investigate temporal changes in rodent densities and in the relationship between $\mathrm{R}_{\mathrm{t}}$ and time-lagged densities. In light of predictions of more frequent and intense $\mathrm{El}$ Niño events, these analyses are important in forecasting changes that may occur in the Fray Jorge small mammal community.

Finally, we also look forward to analyses on the opportunistic species Oligoryzomys longicaudatus, although their low and sporadic numbers make such analyses challenging if not impossible. Ultimately, these analyses will include all core species (O. degus, Phyllotis, Thylamys) as well as a quasi-core species $(A$. olivaceus), and an opportunistic species ( $A$. 
longipilis; sensu Meserve et al. [2003], Milstead et al. [2007]) in the small mammal assemblage. We anticipate that characterizing demographic patterns and driving factors in this manner will lead to a more comprehensive understanding of the dynamics of key small mammal species at our site, and allow us to make predictive assessments of likely responses by these key elements of the fauna in response to climate change, and extrapolate them to predictions at the community level.

\section{2) Importance of other consumer groups - birds}

Until recently, our efforts have concentrated on documenting important linkages between several major subsets of the organismal components of our study system - small mammals, plants (herbage, seeds), and vertebrate predators. Another major consumer group that likely has important links to their predators and/or prey is songbirds, and we initiated studies on these in 2002. Surprisingly little work has been pursued on avian ecology in northern Chile, and hence, we initiated basic censuses as well as documented foraging ecology for select species. Most recently we have begun characterizing plumages in birds at Fray Jorge to distinguish sexes and age classes externally; with this information we hope to initiate formal monitoring of avian productivity and survivorship (e.g., MAPS Monitoring Avian Productivity and Survivorship; DeSante et al. 2008) in the near future.

Birds are the primary granivores at Fray Jorge, followed by small mammals (especially when populations are high); ants are only trivial consumers (Kelt et al. 2004a, 2004b, 2004c). This contrasts with high seed consumption rates by ants (and small mammals) in Northern Hemispheric arid zones (e.g., Brown et al. 1979, Davidson et al. 1980, 1984, 1985, Brown 1987), but supports other studies refuting suggested low granivory overall in South America (Mares \& Rosenzweig 1978, Brown \& Ojeda 1987, Medel \& Vásquez 1994, Medel 1995, Vásquez et al. 1995). Moreover, an extensive seed bank and large guild of granivorous birds has been documented in South American arid zones (e.g., Marone \& Horno 1997, López de Casenave et al. 1998, Marone et al. 1998, 2000,
Gutiérrez \& Meserve 2003). Unlike the documented numerical responses of small mammals to El Niño events, we lack such information for birds. We do know that there are strong seasonal increases in avian populations due to immigration from the Andean foothills and/or southern Chile in the austral winter, and recently, we confirmed transient populations of birds migrating through the park in spring (A. Engilis, unpublished data). Thus, we have focused our work on documenting avian responses to ENSO-induced fluctuations in resource levels, including seasonal and annual demographic fluctuations as well as variation in reproductive patterns and productivity (fledgling success).

In 2002, we verified that variable-radius point counts were the most appropriate means of monitoring avian numbers, and in 2004 we initiated triannual surveys on eight $1 \mathrm{~km}$ transects comprising four stations ca. $250 \mathrm{~m}$ apart crossing the study area. Transects are oriented east-west and are arranged at $1 \mathrm{~km}$ intervals (north-south) to span Quebrada de Las Vacas. Using detection curves we determined that a count of eight minutes was optimal for surveying the scrub habitat of the park. We conducted counts during the postbreeding period (Feb.-Mar.), mid-winter (JulyAug.), and during peak breeding season (Oct.Nov.). All counts were conducted from daybreak to no later than $1,000 \mathrm{hrs}$ on days lacking moderate or strong winds; we conducted all surveys twice (on separate days) to minimize any spurious results. Thus, each survey included 32 point counts sampled twice for a total of $512 \mathrm{~min}$. We determined detectabilities and abundance for key species using DISTANCE (Buckland et al. 2001, Thomas et al. 2006). Surveys conducted during the breeding season are not complete (only three years analyzed and a fourth year only recently obtained) and thus are not included here. To date we have recorded 49 bird species (Table 1), with a mean of just over 30 species per census (Fig. 4).

Considering only birds detected within 50 $m$ of the survey point, over half of our detections comprised only five species (Fig. 5) - chincol (Zonotrichia capensis [Muller, 1776]; $18 \%$ ), yal (Phrygilis fruticeti [Kittlitz, 1833]; 12 $\%)$, canastero (Asthenes humilis [Cabanis, 1873]; 8 \%), tapaculo (Scelorchilus albicollis 


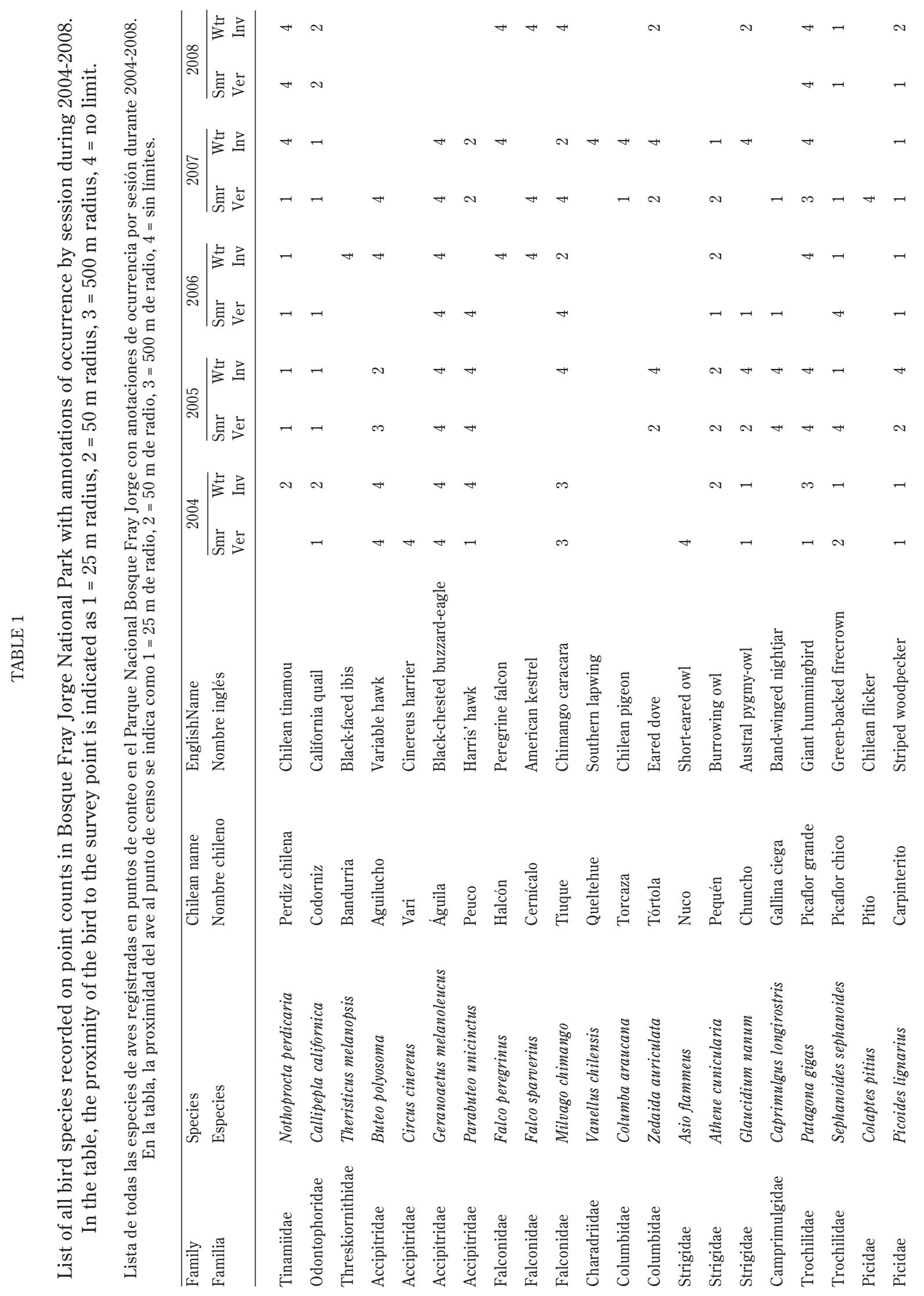




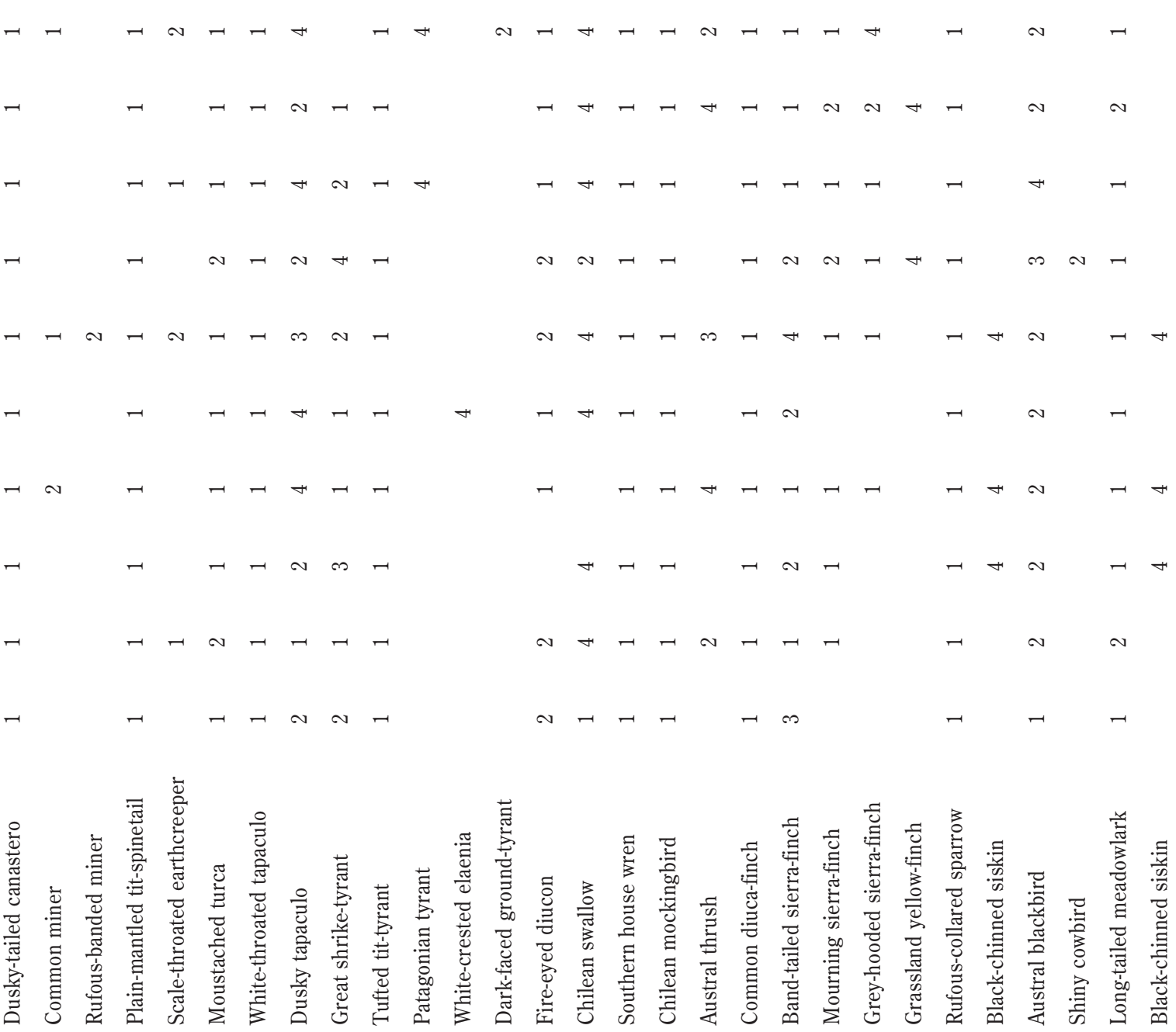

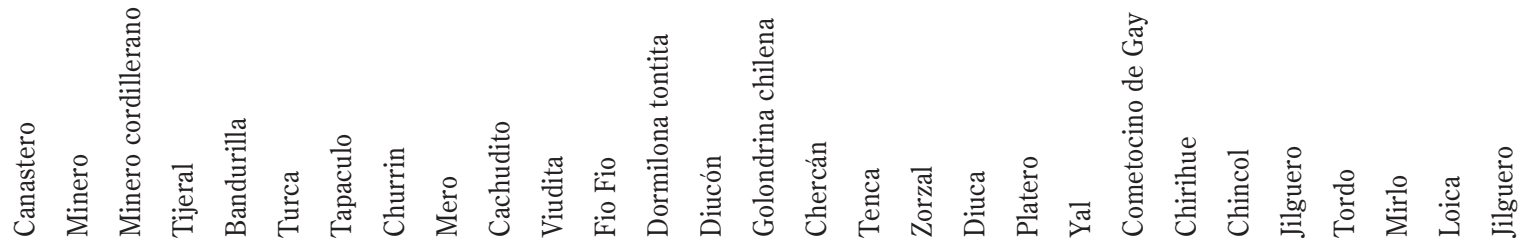

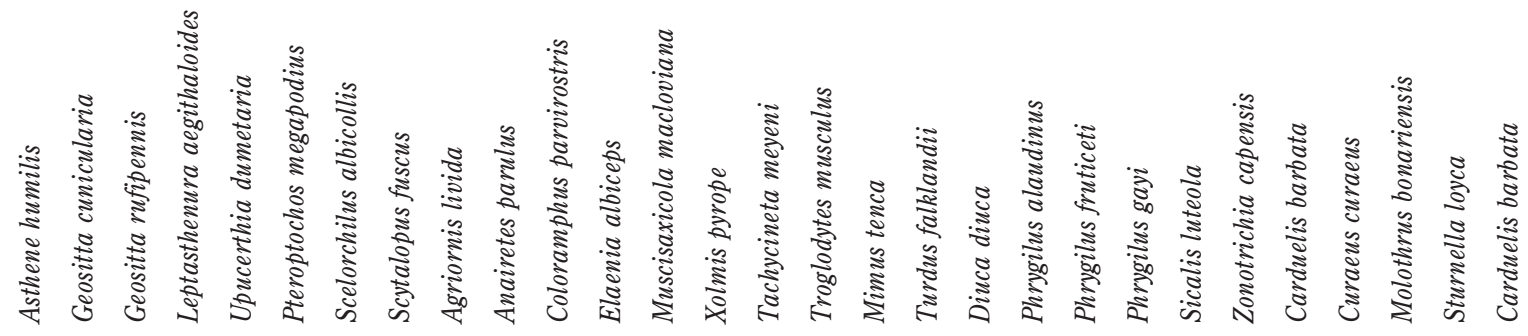

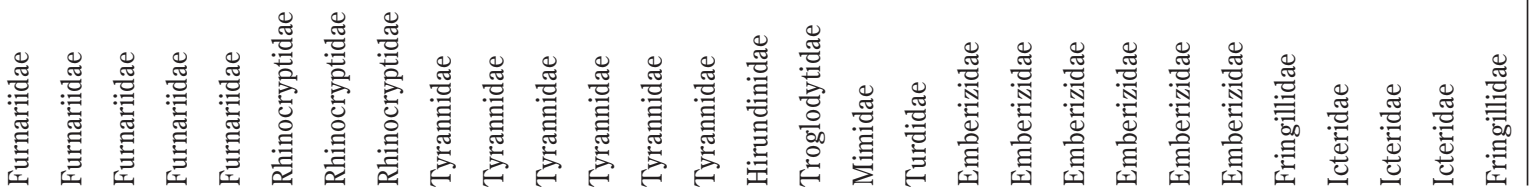


[Kittlitz, 1830]; 8 \%), and diuca (Diuca diuca [Molina, 1782]; 7 \%). Summer and winter data reflect marked changes in faunal composision. In summer over $50 \%$ of detections were of chincol (21\%), canastero (14\%), chercán (Troglodytes aedon Vieillot, 1809; $9 \%$ ), and tapaculo (9\%); in winter these included yal (21 $\%)$, chincol (19\%), diuca (8\%), and tapaculo (7 $\%)$. Species abundance relationships are typical for such assemblages, with few species comprising the majority of observations, and a large tail of rare species observed one to a few times (Fig. 5).

Six species were observed only once within a $50 \mathrm{~m}$ radius. Of these, three (aguilucho [Buteo polyosoma (Quoy \& Gaimard, 1824)], torcaza [Patagioenas araucana (Lesson, 1827)], picaflor gigante [Patagona gigas (Vieillot, 1824)]) are commonly seen at Fray Jorge; the former two were documented frequently at greater distances, and the latter was observed frequently but not documented on point counts. Three other singleton species are commonly observed in northern Chile. Two of these, the minero (Geositta cunicularia [Vieillot, 1816]) and the dormilona tontita (Muscisaxicola macloviana [Garnot, 1829]), are uncommon in the park because these species do not frequent scrublands, but prefer open and barren ground outside the park. The third, the mirlo (Molothrus bonariensis [Gmelin,
1789]), frequents agricultural areas and is rarely observed in the park.

Our data confirm that temporal patterns are species-specific, and that overall, the avian assemblage undergoes dramatic seasonal fluctuations (Table 1). Some species are highly seasonal in their abundance (e.g., yal, present only in winter), whereas others are not clearly seasonal (e.g., diuca, tenca [Mimus thenca (Molina, 1782)], cachudito [Anairetes parulus (Kittlitz, 1830)]), and some (e.g., chincol) appear highly seasonal in most years but notably aseasonal in others (Fig. 6). Detectability is a function of bird behavior and varies across species as well as seasons; most songbirds are much more detectable in the breeding season when they are vocalizing to defend breeding territories or attract mates. This does not explain the dramatic seasonality of yal, however, which generally leave the park in summer, presumably for areas in the Andes or in southern Chile. Chincol at our site also are more abundant in winter (presumably due to the arrival of non-breeding individuals), so we believe the patterns represented in Fig. 6 are valid. On the other hand, to our knowledge tijeral (Leptasthenura aegithaloides [Kittlitz, 1830]), cachudito, and canastero are residents in the park, and the very different numbers in summer and winter requires further investigation. We speculate that in winter

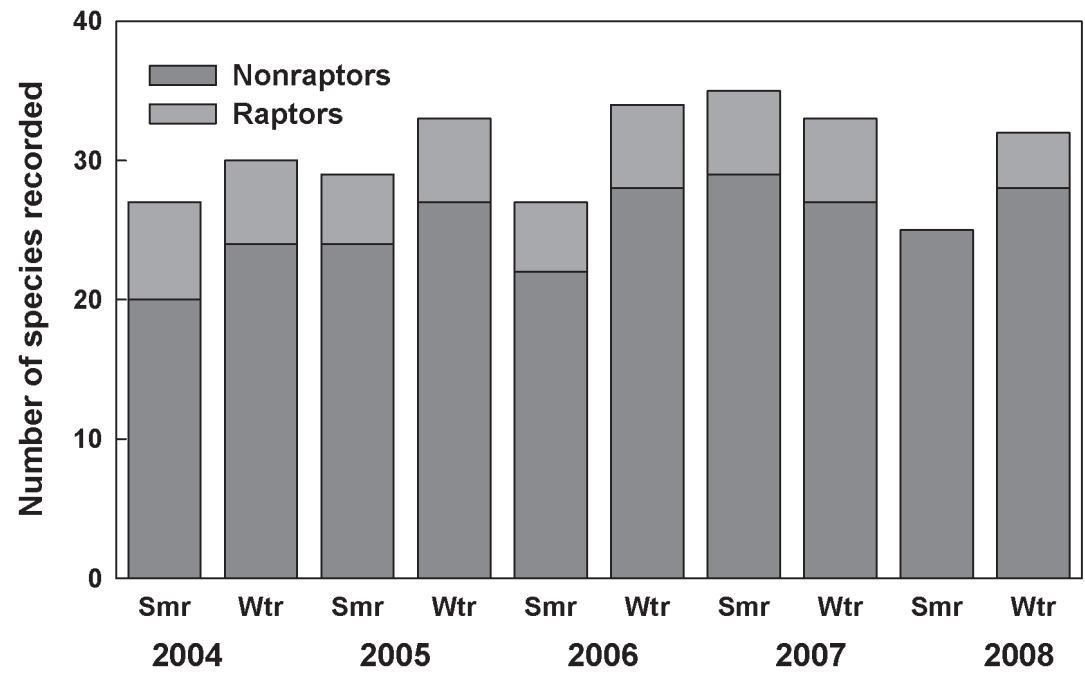

Fig. 4: Number of species separated by raptors vs. nonraptors. Figure includes all birds noted, including "flybys", potentially at great distances.

Número de especies separadas por rapaces vs. no rapaces. La figura incluye todas las aves divisadas, incluyendo "bandadas", potencialmente a gran distancia. 
these insectivores may band to form mixedspecies flocks, call less, and thus may be encountered less frequently. Tencas also are year-round residents in the park, and patterns for this species were similar in both seasons, with a gradual increase from 2004 throughout 2005/06 followed by some variability in numbers in subsequent seasons. These more regular patterns may be explained by the Tenca's mutualistic relationship with the endophytic mistletoe, Tristerix aphyllus (Martínez del Río et al. 1996). Their patterns of distribution in the park are predictable due to their association with cactus that play host to the mistletoe. Tenca have been observed maintaining territories through the winter and to vocalize year-round (A. Engilis, unpublished data). We currently are quantifying densities for other species and we look forward to comparing ecologically related (e.g., trophic) groups of species.

Species diversity (Shannon-Wiener index, H'; Fig. 7) tended to be higher in summer than winter (mean $\mathrm{H}^{\prime}=1.56$ vs. $1.45 ; \mathrm{t}=1.88, \mathrm{P}=$ $0.0621)$. Whereas this parameter varied significantly across all surveys $(\mathrm{F}=291, \mathrm{P}<$ 0.0001 ), a second order regression with time explained little of the variance $\left(r^{2}=0.18\right.$; Fig. 7).

As indicated above, we are now quantifying external indicators of reproductive activity and using these to characterize reproductive patterns and determine age of individual birds more precisely. In 2008, we used mist-netting, marking, and photography to document plumages on 20 species in the park. These data will be supplemented with examination of museum specimens to develop a manual for

\section{Species-abundance relationships}

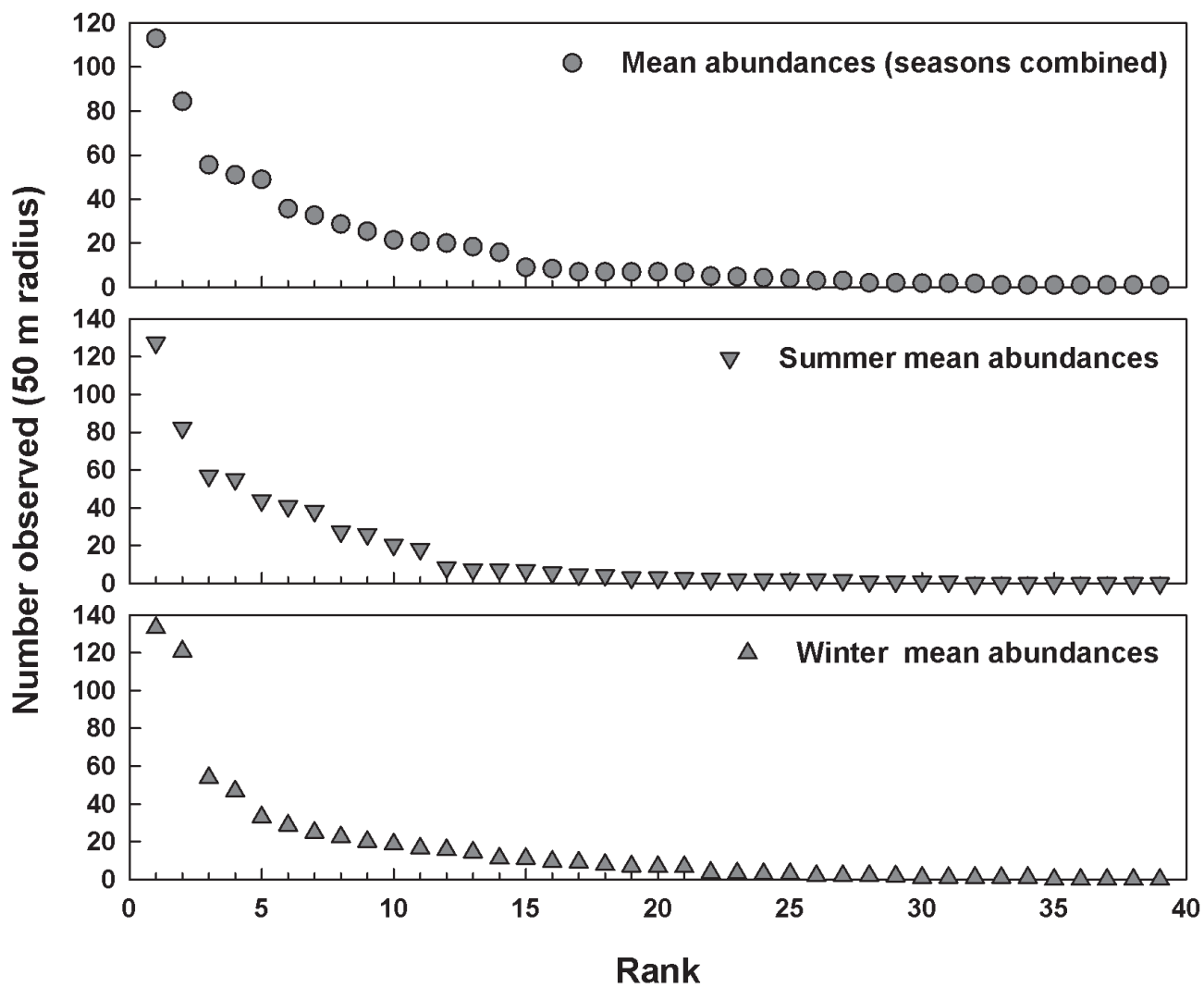

Fig. 5: Rank species abundance curves for all bird data, and summer and winter separately in Bosque Fray Jorge National Park.

Ranking de curvas de abundancia de especies para todos los datos de aves, separadamente para verano e invierno en el Parque Nacional Bosque Fray Jorge. 
ageing and sexing key avian species of Chilean matorral. Such data are entirely absent for species in our assemblage, but will allow us to quantify recruitment (and hence productivity) at a population level, which is more readily accomplished than individual-based recruitment (e.g., fledgling success at focal nests) and avoids problems associated with disturbing nests and possibly providing cues to nest predators. Tracking avian densities and productivity will allow us to quantify responses to resource availability (e.g., precipitation and seed availability in control plots), allowing comparison with our long-term data on mammals. Natural history and descriptive ecology provide the foundation on which more conceptual research can be pursued; to this end, we quantified foraging behavior of the Cachudito in coastal steppe matorral in Fray Jorge (Engilis \& Kelt 2009). Population densities are higher at Fray Jorge than reported elsewhere in Chile and Argentina, and both abundance and ease of observation allowed us to document 94 foraging bouts (77 in summer, 17 in winter) and 709 prey captures. Cachuditos foraged frequently in pairs, leapfrog style, maintaining contact with soft "perrreet" calls. Eighteen agonistic encounters (15 in summer, three in winter) consisted of rapid calling and displacement behaviors, apparently related to territoriality; once an intruder moved away, the defending pair resumed foraging. Cachuditos generally foraged in shrubs proportional to their availability, although our data suggest some preference for Adesmia, Baccharis, or Porlieria (76\% of observations but only $58 \%$ of cover based on line transects). They located prey (insects) visually, and made an average of 3.1 attacks per minute, capturing prey by perch gleaning (47\% of captures), hover gleaning $(31.5 \%)$, and flycatching (21.5\%).
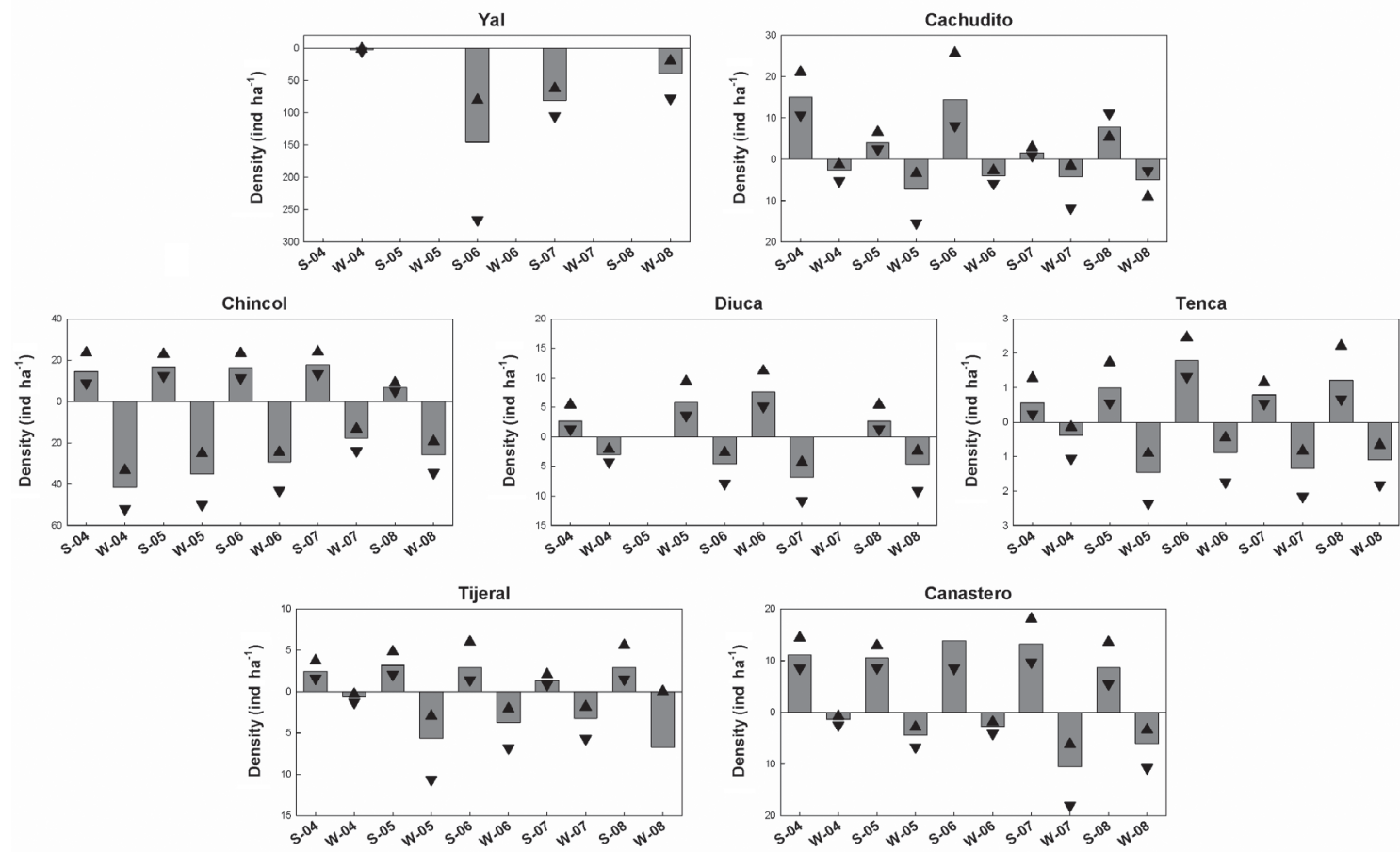

Fig. 6: Temporal patterns in seven bird species at Fray Jorge over four years. Values for summer are above the horizontal line, whereas those for winter are presented below the horizontal line. Densities (bars) and confidence limits ( $\bullet$ and $\boldsymbol{\nabla}$ ) were calculated using Program Distance (Laake et al. 1993).

Patrones temporales de siete especies de aves en Fray Jorge en cuatro años. Valores por verano están presentados arriba de la línea horizontal, mientras que estos por invierno están presentados debajo de la línea. Densidades (barras) y límites de confianza $(\wedge \mathrm{y} \bullet$ ) se calcularon usando el programa Distance (Laake et al. 1993). 
3) Impacts of introduced vs. native species in the context of changing environmental conditions

Introduced plants comprise $18 \%$ of the Chilean flora, including $27 \%$ of herbaceous plants. Some naturalized species (e.g., Erodium, Medicago polymorpha, Malva nicaensis) constitute up to $45 \%$ of the vegetation in Chilean matorral (Arroyo et al. 2000, Figueroa et al. 2004). Changes in the proportions of exotic species have been attributed to the effects of exotic grazers (Holmgren 2002) and fire (Sax 2002, Kunst et al. 2003; but see Holmgren et al. 2000a, 2000b). In Fray Jorge, where fire and most livestock have been absent at least since 1944 , exotic plants comprise up to $21 \%$ of the herbaceous species, and $19 \%$ of the seed bank species (Gutiérrez \& Meserve 2003). In contrast to plants, only 24 of 610 vertebrate species in continental Chile (4 $\%)$ are introduced (Jaksic 1998a, Iriarte et al. 2005). However, the negative impacts of introduced murid rodents (Rattus rattus [Linnaeus, 1758], $R$. norvegicus [Berkenhout, 1769], Mus musculus Linnaeus) and lagomorphs (Oryctolagus cuniculus [Linnaeus, 1758], Lepus europaeus Pallas, 1778) have been well-documented (murids, Lobos et al. 2005, Milstead et al. 2007; lagomorphs, Jaksic 1998b). Jaksic (1998b) described positive effects of rabbits and hares on indigenous vertebrate predators including pumas, diurnal hawks, and owls, but also noted that predators apparently neglected to utilize these until the late 1980's. In Fray Jorge, rabbit and hare populations were relatively low until recently (Meserve et al. pers. observ.) simultaneous with the prolonged El Niño/ high rainfall event in 2000-2002 and a sharp decrease in the numbers of foxes caused by an outbreak of parvovirus, rabbit and hare numbers increased dramatically in the park. Experimental work immediately $\mathrm{S}$ of Fray Jorge demonstrated significant effects of rabbit and hare exclusion, including a $90 \%$ increase in survival of Prosopsis chilensis (an arborescent shrub largely extirpated from arid northern Chile), increases in tall native grasses (e.g., Bromus berteroanus), and decreases in native and exotic prostrate ephemerals (Gutiérrez et al.

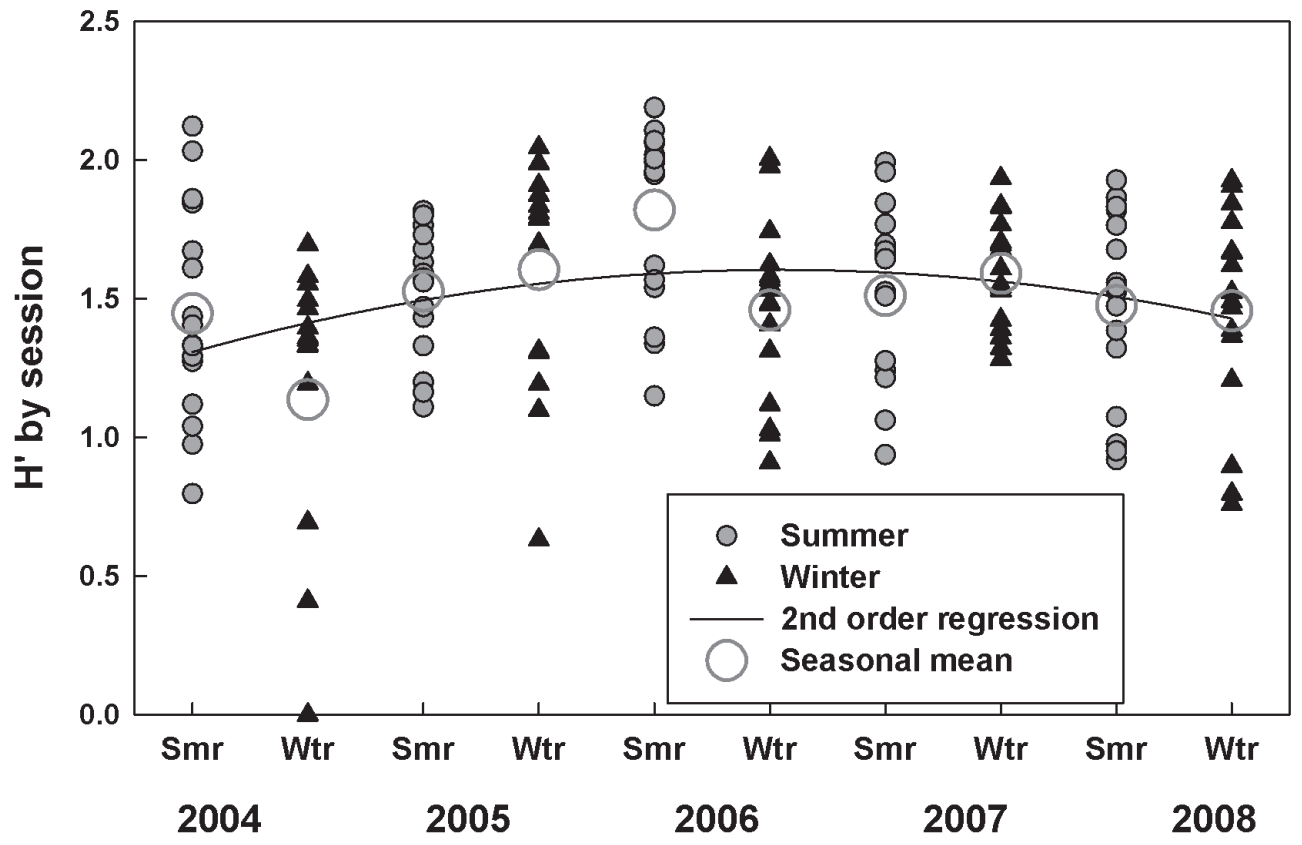

Fig. 7: Bird species diversity (H') for summer and winter periods over five years at Bosque Fray Jorge National Park. The quadratic regression $\left(\mathrm{H}^{\prime}=1.18+1.39 \mathrm{x}-0.01 \mathrm{x}^{2}\right)$ is highly significant $\left(\mathrm{F}_{10,150}=291, \mathrm{P}<0.0001\right)$ but explains little of the variation $\left(\mathrm{r}^{2}=0.058\right)$.

Diversidad de especies de aves (H') para los períodos de verano e invierno en cinco años en el Parque Nacional Bosque Fray Jorge. La regresión cuadrática $\left(\mathrm{H}^{\prime}=1.18+1.39 \mathrm{x}-0.01 \mathrm{x}^{2}\right)$ es altamente significativa $\left(\mathrm{F}_{10,150}=291, \mathrm{P}<\right.$ $0.0001)$ pero explica poco de la variación $\left(\mathrm{r}^{2}=0.058\right)$. 
2007). Additional exclusion of herbivores under conditions of simulated high rainfall increased overall plant productivity, and favored native species (Manrique et al. 2007). Access by lagomorphs reduced native grass biomass and facilitated invasive grasses; thus, lagomorph herbivory may affect plant community structure and composition by influencing competitive dynamics between native and exotic plant species.

As noted earlier, we converted D-P grids to -SM treatments in 2001. To investigate the potential effects of introduced herbivore/ folivores in the thorn scrub community in Fray Jorge, we initiated an additional series of exclusions using former degu exclusions ($\mathrm{D}+\mathrm{P})$ plus four new experimental grids in 2007 (see Fig. 1); as noted above, there have been few discernible changes in the vegetation or seed bank attributable to the exclusion of degus here. We converted two former $-\mathrm{D}+\mathrm{P}$ grids (randomly selected) plus two new experimental grids to lagomorph exclusion grids (-L) by removing existing fencing and installing ca. $1.5 \mathrm{~m} \mathrm{~h}$ chain link fencing buried ca. $20 \mathrm{~cm}$. The remaining two $-\mathrm{D}+\mathrm{P}$ plus two food addition grids were converted to all-small mammal \& lagomorph (-SM -L) exclusions by use of the -SM fencing design supplemented with a $1.5 \mathrm{~m}$ h chain link fencing inside it. Grid conversion was completed, and small mammal trapping and both vegetation and seed bank sampling initiated, in late 2007.

Attempts to monitor lagomorphs with spotlight surveys and live-trapping have proved unsuccessful in this densely-covered shrubland; to quantify patterns in lagomorph numbers at our site, we initiated indirect inventory techniques in August 2007. We established 54 pellet count stations (Lazo 1992, Diaz 1998, Palomares 2001, Murray et al. 2002, 2005, Mills et al. 2005) in six lines of nine stations each. Stations are ca. $100 \mathrm{~m}$ apart and established to sample the central grid complex. All pellets within a $1 \mathrm{~m}$ radius of a central stake were removed, and all new pellets are counted and removed at six-month intervals.

We predict strong vegetative responses to the combined exclusion of small mammals and lagomorphs, particularly in high rainfall years when plants show the strongest numerical increases. This may alter community composition as well as interspecific interactions among various plant groups. A mild La Niña event in 2007 made the timing of the initiation of our studies of lagomorph and small mammal + lagomorph exclusions auspicious. Based on earlier results (Gutiérrez et al 2007, Manrique et al. 2007), exclusion of larger mammalian herbivores such as lagomorphs should influence vegetation dynamics especially among the herbaceous plant guild in the thorn scrub. Further, effects of lagomorphs and smaller mammals may be cumulative in total exclusion treatments.

\section{CONCLUSIONS}

With 20 years of constant data collection, many of our initial perceptions on how components of the Chilean semiarid community function and interact have required continued revision. Whereas we initiated our work on the presumption of a strong overwhelming role of biotic interactions, abiotic factors have been shown to have a strong and often determining role. Further, models of small mammal dynamics here call for incorporation of spatial and temporal heterogeneity to understand overall assemblage dynamics. Other components of the system such as birds may also be important, but to date remain understudied. Finally, we must interpret the changes that are occurring in the system against a background of a large and influential component of invasive species as well as ongoing climatic change. The latter aspect may be the most important factor that needs to be addressed.

In recent decades, rainfall had been declining in the northern Chilean semiarid zone, continuing a gradual aridity trend over the past 1,000 years (Bahre 1979, Villalba 1994). Since 2000, however, five of the past nine years have seen above average precipitation; moreover, the three largest El Niño events of the past 100 years have occurred since 1982 (Gergis \& Fowler 2009). Although there has been little change in small mammal assemblage and shrub cover here over 50 years, El Niño has been shown to facilitate outbreaks of small mammals and to influence agriculture elsewhere (e.g., Pearson 1975, Péfaur et al. 1979, Fuentes \& Campusano 1985, Jiménez et al. 1992, Jaksic 2001, Jaksic \& 
Lima 2003, Holmgren et al. 2006a, 2006b, Sage et al. 2007). Holmgren \& Scheffer (2001) and Holmgren et al. (2001, 2006a, 2006b) emphasized that more frequent El Niño/ rainfall events may reverse or ameliorate the general desertification of much of northcentral semiarid Chile (Bahre 1979, Schofield \& Bucher 1986, Ovalle et al. 1993). Superimposed on this, increased frequency and intensity of El Niño events as a consequence of GCC may greatly alter the relative importance of biotic and abiotic interactions in semiarid systems. Increasing rainfall may have strong impacts such as altering patterns of nutrient cycling and primary productivity (e.g., Gutiérrez 1993, 2001, Jaksic 2001, Reich et al. 2006, de la Maza et al. 2009), species interactions and community diversity (e.g., Chesson et al. 2004, Holmgren et al. 2001, 2006a, 2006b), disease vectors, reservoirs, and zoonoses (Epstein 1999, 2000, Epstein \& Mills 2005), and the impact of introduced species (e.g., Jaksic 1998, 2001, Logan et al. 2003).

We recognize that an alternative climate change scenario could occur in this region; our understanding of interactions between global warming and ENSO and, in turn, between ENSO and local environments, continues to improve. For example, increased rainfall during El Niño events increases productivity at lower elevations in this region, but not at higher elevations due to colder temperatures (Squeo et al. 2006). Further, the influence of fog from the Pacific Ocean, an important contributor to local moisture in this semi-arid region (Kummerow 1962, del-Val et al. 2006), is reduced during El Niño years (Garreaud et al. 2008).

Finally, we acknowledge uncertainty regarding the strength and even the reality of a causal link between the observed demographic patterns and climate change (McCarty 2001), especially due to a number of constraints that exist when attempting to anticipate the effects of climate change based on knowledge of current conditions (Berteaux et al. 2006). Nevertheless, our study contributes to the growing body of studies in this field that is helping to develop a more comprehensive understanding of the potential effects of climate change (McCarty 2001). Our study is unique in that it implicates increased rains as the climate change driver, documents clear responses in community parameters, and provides insight to climatic influences on small mammal species, all of which are seldom reported in the literature on climate change impacts.

Long-term research on small mammal assemblages in arid systems has been productive in our understanding of ecosystem processes. Recent studies have emphasized the role of local ecological compensation and "zero-sum dynamics" within the context of a regional species pool (e.g., Ernest et al. 2008). Such dynamics assume a diverse pool of species as potential colonists. Chile has relatively low beta diversity of both birds and small mammals (Cody 1975, Glanz \& Meserve 1982) and as such it is unlikely that spatiotemporal signals in terrestrial ecology at our site will be similar to those documented elsewhere. To test this conjecture we are preparing to quantify ecosystem properties including energy utilization across grids and over time. In particular, we are eager to compare small mammal assemblages on predator and lagomorph removal plots with those on controls.

Many authors have stressed the importance of both spatial and temporal scale in ecology, and of the dearth of studies extending across large spatial scales or many years (e.g., Wiens et al. 1986, Giller \& Gee 1987, Powell 1989, Wiens 1989, Levin 1992, Polis et al. 1996, Schneider 2001). Recently, Agrawal et al. (2007) recognized that the strength and outcomes of species interactions depends on the biotic and abiotic context in which they occur, a fact borne out clearly by results of our studies. Now the longest field manipulation in the temperate neotropics, and spanning five El Niño/high rainfall events in 20 years of study, our work has documented variable effects of biotic interactions depending on the abiotic context.

In this context, the role of long-term ecological studies such as this one assumes great importance. For example, since about 2000 , we have noted a tendency for small mammal biomass in Fray Jorge to be dominated by the larger, more mesic-adapted caviomorph rodent, O. degus (Meserve et al. 2009); further, degus are showing greater survival and recruitment in the last 10 years (Previtali et al. 2010). Small mammal species diversity has also become more stable and less 
oscillatory at the site (Meserve et al. 2009). This has occurred concomitant with the increase in mean annual precipitation since 2000, and less-pronounced interannual variation (Fig. 3). Without long-term studies such as this one, we would not have been able to detect such changes, nor compare them against a background of prevailing population fluctuations in response to periodic El Niño events. Determining whether such trends signal a major shift in small mammal (and other biotic) components will only be feasible with continued maintenance of long-term monitoring efforts in this unique part of Chile.

\section{SUPPLEMENTARY MATERIAL}

The Spanish version of this article is available as online Supplementary Material at http:// rchn.biologiachile.cl/suppmat/2010/1/ SM_Gutierrez_et_al_2010.pdf

\section{ACKNOWLEDGEMENTS}

We are grateful to many, many collaborators, technicians, consultants, and independent researchers too numerous to mention who have worked on this research or contributed to its success. We particularly acknowledge the personnel and administration of the Corporación Nacional Forestal (CONAF) for their permission to use Bosque Fray Jorge National Park as the site of a large experimental array. Financial support has been provided by many grants from the U.S. National Science Foundation and FONDECYT Chile including most recently, NSF-LTREB DEB-03-19966 to P.L.M. and D.A.K., and FONDECYT No. 1070808 to J.R.G. Bird research has been funded through grants and support from the UC Davis Selma Herr Fund for Ornithology and the UC Davis Museum of Wildlife and Fish Biology. The Universidad de La Serena and Northern Illinois University have provided valuable logistical and financial support as well as use of their facilities throughout the duration of the research. Since 2008, financial support from Instituto de Ecología y Biodiversidad (IEB) and Basal Fund PB-23 has allowed us to continue with field data collection.

\section{LITERATURE CITED}

ABRAMS P, BA MENGE, GG MITTELBACH, D SPILLER \& P YODZIS (1996) The role of indirect effects in food webs. In: Polis GA \& KO Winemiller (eds) Food webs: Integration of patterns and dynamics: 371-395. Chapman \& Hall, New York, NY

AGRAWAL AA, DD ACKERLY, F ADLER, AE ARNOLD, C CÁCERES et al. (2007) Filling key gaps in population and community ecology. Frontier in Ecology and Environment 5: 145-152.

ANDREWARTHA HG \& LC BIRCH (1954) The distribution and abundance of animals. University Chicago Press, Chicago, IL.

ARIM M \& FM JAKSIC (2005) Productivity and food web structure: Association between productivity and link richness among top predators. Journal of Animal Ecology 74: 31-40.

ARIM M, PA MARQUET \& FM JAKSIC (2006) On the relationship between productivity and food chain length at different ecological levels. American Naturalist 169: 62-72.

ARMESTO JJ, PE VIDIELLA \& JR GUTIÉRREZ (1993) Plant communities of the fog-free coastal desert of Chile: Plant strategies in a fluctuating environment. Revista Chilena de Historia Natural 66: 271-282.

ARROYO MTK, C MARTICORENA, O MATTHEI \& L CAVIERES (2000) Plant invasions in Chile: Present patterns and future predictions. In: Mooney HA \& R Hobbs (eds) Invasive species in a changing world: 384-421. Island Press, Covelo, CA.

BAHRE CJ (1979) Destruction of the natural vegetation of north-central Chile. University of California Publications in Geography 23: 1-118.

BENDER EA, TJ CASE \& ME GILPIN (1984) Perturbation experiments in community ecology: Theory and practice. Ecology 65: 1-13.

BERLOW EL, A-M NEUTEL, JE COHEN, PC DE RUITER, B EBENMAN et al. (2004) Interaction strengths in food webs: Issues and opportunities. Journal of Animal Ecology 73: 585-598.

BERRYMAN AA (1999) Principles of population dynamics and their applications. Stanley Thornes Publishers Ltd., Cheltenham, UK.

BERRYMAN AA \& M LIMA (2007) Detecting the order of population dynamics from time series: Nonlinearity causes spurious diagnosis. Ecology 88: 2121-2123.

BERRYMAN AA \& P TURCHIN (2001) Identifying the density-dependent structure underlying ecological time series. Oikos 92: 265-270.

BERTEAUX D, MM HUMPHRIES, CJ KREBS, M LIMA, AG MCADAM et al. (2006) Constraints to projecting the effects of climate change on mammals. Climate Research 32: 151-158.

BJØRNSTAD ON, M BEGON, N CHR STENSETH, W FALCK, S SAIT \& DJ THOMPSON (1998) Population dynamics of the Indian meal moth: Demographic stochasticity and delayed regulatory mechanisms. Journal of Animal Ecology 67: 110-126.

BLOCK MA \& M RICHTER (2000) Impacts of heavy rainfalls in El Niño 1997/98 on the vegetation of the Sechura Desert in northern Peru. Phytocoenologia 30: 491-517.

BODKIN DB, H SAXE, MB ARAÚJO, R BETTS, RHW BRADSHAW et al. (2007) Forecasting the effects 
of global warming on biodiversity. BioScience 57: 227-236.

BOX GEP \& JM JENKINS (1976) Time series analyses: Forecasting and control. Holden-Day, Inc., San Francisco, CA.

BOZINOVIC F (1995) Nutritional, energetic, and digestive responses of an herbivorous rodent (Octodon degus) to different levels of dietary fiber. Journal of Mammalogy 76: 627-637.

BROWN JH (1987) Variation in desert rodent guilds: Patterns, processes, and scales. In: Gee JRH \& PS Giller (eds) Organization of communities past and present: 185-203. Blackwell Sciences Publication, Oxford, England.

BROWN JH (1998) The granivory experiments at Portal. In: Resetarits WL JR \& J Bernardo (eds) Experimental ecology: Issues and perspectives: 71-95. Oxford University Press, Oxford.

BROWN JH \& SKM ERNEST (2002) Rain and rodents: Complex dynamics of desert consumers. BioScience 52: 979-987.

BROWN JH \& EJ HESKE (1990a) Control of a desertgrassland transition by a keystone rodent guild. Science 250: 1705-1707.

BROWN JH \& EJ HESKE (1990b) Temporal changes in a Chihuahuan Desert rodent community. Oikos 59: 290-302

BROWN JH \& RA OJEDA (1987) Granivory: Patterns, processes, and consequences of seed consumption in two continents. Revista Chilena de Historia Natural 60: 337-349.

BROWN JH, OJ REICHMAN \& DW DAVIDSON (1979) Granivory in desert ecosystems. Annual Review of Ecology \& Systematics 10: 201-227.

BROWN JH, DW DAVIDSON, JC MUNGER \& RS INOUYE (1986) Experimental community ecology: The desert granivore system. In: Diamond J \& TJ Case (eds) Community ecology: 41-61. Harper \& Row, New York, NY.

BUCKLAND ST, DR ANDERSON, KP BURNHAM, JL LAAKE, DL BORCHERS \& L THOMAS (2001) Introduction to distance sampling. Oxford University Press, New York, NY.

CASTRO SA, SI SILVA, PL MESERVE, JR GUTIÉRREZ, LC CONTRERAS \& FM JAKSIC (1994) Frugivoría y dispersión de semillas de pimiento (Schinus molle) por zorros culpeo (Pseudalopex culpaeus) en el Parque Nacional Fray Jorge (IV Región, Chile). Revista Chilena de Historia Natural 67: 169-176.

CHESSON P, RLE GEBAUER, S SCHWINNING, N HUNTLEY, K WIEGAND et al. (2004) Resource pulses, species interactions, and diversity maintenance in arid and semi-arid environments. Oecologia 141: 236-253.

CLIVAR (1992) Climate variability and predictability world climate research programme. A study of climate variability and predictability. World Meterological Organization, Geneva, Switzerland.

CODY ML (1975) Towards a theory of continental species diversity: Birds distributions on mediterranean habitat gradients. In: Cody ML \& JM Diamond (eds) Ecology and evolution of communities: 214-257. Harvard University Press, Cambridge, MA.

CODY ML \& JA SMALLWOOD (eds) (1996) Long-term studies of vertebrate communities. Academic Press, New York, NY.

COULSON T, EA CATCHPOLE, SD ALBON, BJT MORGAN, JM PEMBERTON, TH CLUTTON-
BROCK, MJ CRAWLEY \& BT GRENFELL (2001) Age, sex, density, winter weather, and population crashes in soay sheep. Science 292: 1528-1531.

COULSON T, F GUNINESS, J PEMBERTON \& TH CLUTTON-BROCK (2004) The demographic consequences of releasing a population of red deer from culling. Ecology 85: 411-422.

CURTIN CG, DA KELT, TC FREY \& JH BROWN (2000) On the role of small mammals in mediating biotic and abiotic interactions in structuring southwestern communities and landscapes. Ecology Letters 3: 309-317.

DAVIDSON DW, JH BROWN \& RS INOUYE (1980) Competition and the structure of granivore communities. BioScience 30: 233-238.

DAVIDSON DW, RS INOUYE \& JH BROWN (1984) Granivory in a desert ecosystem: Experimental evidence for indirect facilitation of ants by rodents. Ecology 65: 1780-1786

DAVIDSON DW, DA SAMSON \& RS INOUYE (1985) Granivory in the Chihuahuan Desert: Interactions within and between trophic levels. Ecology 66: 486-502.

DE LA MAZA M, M LIMA, PL MESERVE, JR GUTIÉRREZ \& FM JAKSIC (2009) Primary production dynamics, climate variability, and its ecological consequences in semiarid Chile. Global Change Biology 15: 1116-1126.

DEL-VAL E, JJ ARMESTO, O BARBOSA, DA CHRISTIE, AG GUTIÉRREZ, CG JONES, PA MARQUET \& KC WEATHERS (2006) Rain forest islands in the Chilean semiarid region: Fog-dependency, ecosystem persistence and tree regeneration. Ecosystems 9: 598-608.

DESANTE DF, P PYLE, N MICHAEL \& D O'GRADY (2003) The 2002 annual report of the monitoring avian productivity and survivorship (MAPS) program at the nature reserve of orange County. The Institute for Bird Populations (Report).

DESANTE DF, KM BURTON, P VÉLEZ, D FROEHLICH \& D KASCHUBE (2008) MAPS manual: 2008 protocol. Instructions for the establishment and operation of constant-effort bird-banding stations as part of the Monitoring Avian Productivity and Survivorship (MAPS) program. The Institute for Bird Populations, Point Reyes Station, CA (online) URL: http:// www.birdpop.org/maps.htm.

DESY EA \& GO BATZLI (1989) Effect of food availability and predation on prairie vole demography: A field experiment. Ecology 70 : 411-421.

DÍAS PC (1996) Sources and sinks in population biology. Trends in Ecology and Evolution 11: 326-330.

DÍAZ A (1998) Comparison of methods for measuring rabbit incidence on grasslands. Mammalia 62: 205-212.

DÍAZ HF, MP HOERLING \& JK EISCHEID (2001) ENSO variability, teleconnections and climate change. International Journal of Climatology 21: 1845-1862.

DILLON MO \& PW RUNDEL (1990) The botanical response of the Atacama and Peruvian Desert floras to the 1982-83 El Niño event. In: Glynn PW (ed) Global ecological consequences of the 1982-83 El Niño event: 487-504. Elsevier Oceanography Series, New York, NY.

DUNSON WA \& J TRAVIS (1991) The role of abiotic 
factors in community organization. American Naturalist 138: 1067-1091.

ELLIS AM \& E POST (2004) Population response to climatic change: Linear vs. nonlinear modeling approaches. BMC Ecology 4, No. 2.

ENGILIS JR, A \& DA KELT (2009) Foraging behavior of the tufted tit-tyrant in semiarid north central Chile. The Wilson Journal of Ornithology 121: 585-592.

EPSTEIN PR (1999) El Niño and health. Science 285: 347-349.

EPSTEIN PR (2000) Is global warming harmful to health? Scientific American 282: 50-57.

EPSTEIN PR \& E MILLS (eds) (2005) Climate change futures: Health, ecological and economic dimensions. Center for Health and Global Development, Harvard Medical School, Cambridge, MA.

ERNEST SKM \& JH BROWN (2001a) Homeostasis and compensation: The role of species and resources in ecosystem stability. Ecology 82: 2118-2132.

ERNEST SKM \& JH BROWN (2001b) Delayed compensation for missing keystone species by colonization. Science 292: 101-104.

ERNEST SKM, JH BROWN \& RR PARMENTER (2000) Rodents, plants, and precipitation: Spatial and temporal dynamics of consumers and resources. Oikos 88: 470-482.

ERNEST SKM, JH BROWN, KM TIBAULT, EP WHITE \& JR GOHEEN (2008) Zero sum, the niche, and metacommunities: Long-term dynamics of community assembly. American Naturalist 172: E257-E269.

FARIAS AA \& FM JAKSIC (2007) Effects of functional constraints and opportunism on the functional structure of a vertebrate predator assemblage. Journal of Animal Ecology 76: 246-257.

FEDOROV AV \& SG PHILANDER (2000) Is El Niño changing? Science 288: 1997-2002.

FIELD CB, FS CHAPIN III, PA MATSON \& HA MOONEY (1992) Responses of terrestrial ecosystems to the changing atmosphere: A resource-based approach. Annual Review of Ecology \& Systematics 23: 201-235.

FIGUEROA JA, SA CASTRO, PA MARQUET \& FM JAKSIC (2004) Exotic plant invasions to the mediterranean region of Chile: Causes, history and impacts. Revista Chilena de Historia Natural 77: 465-483.

FORCHHAMMER MC, NCHR STENSETH, E POST \& R LANGVATN (1998) Population dynamics of Norwegian red deer: Density-dependence and climatic variation. Proceedings of the Royal Society London B 265: 341-350.

FOX GA (2001) Failure-time analyses: Studying times to events and rates at which events occur. In: Scheiner SM \& J Gurevitch (eds) Design and analysis of ecological experiments: 235-266. Second edition. Oxford University Press, New York, NY.

FUENTES ER \& C CAMPUSANO (1985) Pest outbreaks and rainfall in the semi-arid region of Chile. Journal of Arid Environments 8: 67-72.

FULK GW (1975) Population ecology of rodents in the semiarid shrublands of Chile. Occassional Papers, The Museum, Texas Tech University 33: 1-40.

FULK GW (1976a) Owl predation and rodent mortality: A case study. Mammalia 40: 423-427.

FULK GW (1976b) Notes on the activity, reproduction, and social behavior of Octodon degus. Journal of Mammalogy 57: 495-505.

GARREAUD R, J BARICHIVICH, DA CHRISTIE \& A MALDONADO (2008) Interannual variability of the coastal fog at Fray Jorge relict forests in semiarid Chile. Journal of Geophysical Research 113: G04011.

GERGIS JL \& AM FOWLER (2009) A history of ENSO events since A.D. 1525: Implications for future climate change. Climate Change 92: 343-387.

GILLER PS \& JHR GEE (1987) The analysis of community organization: The influence of equilibrium, scale and terminology. In: Gee JHR \& PS Giller (eds) Organization of communities past and present: 519-542. Blackwell Science Publications, Oxford, England.

GLANZ WE \& PL MESERVE (1982) An ecological comparison of small mammal communities in California and Chile. In: Conrad CE \& WC Oechel (eds) Dynamics and management of Mediterranean-type ecosystems: 220-226. U.S. Forest Service, Pac. SW Forest Range Experimental Station, General Technical Report PSW-58: 1-637. Berkeley, CA.

GRENFELL BT, K WILSON, BF FINKENSTÄDT, TN COULSON, S MURRAY et al. (1998) Noise and determinism in synchronised sheep dynamics. Nature 394: 674-677.

GUO Q, DB THOMPSON, TJ VALONE \& JH BROWN (1995) The effects of vertebrate granivores and folivores on plant community structure in the Chihuahuan desert. Oikos 73: 251-259.

GUTIÉRREZ JR (1993) The effect of water, nitrogen, and human-induced desertification on the structure of ephemeral plant communities in the Chilean coastal desert. Revista Chilena de Historia Natural 66: 337-344.

GUTIÉRREZ JR (2001) Dynamics of ephemeral plants in the coastal desert of north-central Chile. In: Prakash I (ed) Ecology of desert environments: 105-124. Scientific Publishers, Jodhpur, India.

GUTIÉRREZ JR, PL MESERVE, FM JAKSIC, LC CONTRERAS, S HERRERA \& H VÁSQUEZ (1993) Dynamics and structure of vegetation in a Chilean semiarid thorn scrub community. Acta Oecologica 14: 271-285.

GUTIÉRREZ JR, PL MESERVE, LC CONTRERAS, H VÁSQUEZ \& FM JAKSIC (1993b) Spatial distribution of soil nutrients and ephemeral plants underneath and outside the canopy of Porlieria chilensis (Zygophyllaceae) shrubs in arid coastal Chile. Oecologia 95: 347-352.

GUTIÉRREZ JR, PL MESERVE, S HERRERA, LC CONTRERAS \& FM JAKSIC (1997) Effects of small mammals and vertebrate predators on vegetation in the Chilean semiarid zone. Oecologia 109: 398-406.

GUTIÉRREZ JR \& F BOZINOVIC (1998) Diet selection in captivity by a generalist herbivorous rodent (Octodon degus) from the Chilean coastal desert. Journal of Arid Environments 39: 601-607.

GUTIERREZ JR \& PL MESERVE (2000) Density and biomass responses of ephemeral plants to experimental exclusions of small mammals and their vertebrate predators in the Chilean arid zone. Journal of Arid Environments 45: 173-181.

GUTIÉRREZ JR \& PL MESERVE (2003) El Niño effects on the soil seed bank dynamics in north-central Chile. Oecologia 134: 511-517.

GUTIÉRREZ JR, G ARANCIO \& FM JAKSIC (2000) 
Variation in vegetation and seed bank in a Chilean semi-arid community affected by ENSO 1997. Journal of Vegetation Sciences 11: 641-648.

GUTIÉRREZ JR, P. MESERVE \& FM JAKSIC (2000b) Efectos de la corriente de El Niño en la biota terrestre de ecosistemas áridos de Sudamérica. In: Jimenez-Milon P, C Talavera-Delgado, L Villegas-Paredes, A Ortega-Paredes \& F Villasante-Benavides (eds) Ecología y desarrollo sostenible: Desafío de América Latina para el tercer milenio: 91-94. Proceedings, IV Congreso Latinoamericano de Ecologia, Industria Gráfica Regentus R.S. Ltda., Arequipa, Perú.

GUTIERREZ JR, M HOLMGREN, R MANRIQUE \& FA SQUEO (2007) Reduced herbivore pressure under rainy ENSO conditions could facilitate dryland reforestation. Journal of Arid Environments 168: 322-330.

HEDGES LV, J GUREVITCH \& PS CURTIS (1999) The meta-analysis of response ratios in experimental ecology. Ecology 80: 1150-1156.

HERBERT JM \& RW DIXON (2002) Is the El Niño phenomenon changing as a result of global warming? Physical Geography 23: 196-211.

HILBORN R, JA REDFIELD \& CJ KREBS (1976) On the reliability of enumeration for mark and recapture census of voles. Canadian Journal of Zoology 54: 1019-1024.

HOBBS RJ \& HA MOONEY (2005) Invasive species in a changing world: The interactions between global change and invasives. In: Mooney HA, RN Mack, JA McNeely, LE Neville, PJ Schei \& JK Waage (eds) Invasive alien species: A new synthesis: 310-331. Island Press, Washington, DC.

HOFFMANN A (1989) Flora silvestre de Chile: Zona central. Segunda edición. Ediciones Fundación Claudio Gay, Santiago, Chile.

HOLMGREN M (2002) Exotic herbivores as drivers of plant invasions and switch to ecosystem alternative states. Biological Invasions 4: 25-33.

HOLMGREN M, MR AVILES, L SIERRALTA, AM SEGURA \& ER FUENTES (2000) Why have European herbs so successfully invaded the Chilean matorral? Effects of herbivory, soil nutrients, and fire. Journal of Arid Environments 44: 197-211.

HOLMGREN M, AM SEGURA \& ER FUENTES (2000b) Limiting mechanisms in the regeneration of the Chilean matorral: Experiments on seedling establishment in burned and cleared mesic sites. Plant Ecology 147: 49-57.

HOLMGREN M \& M SCHEFFER (2001) El Niño as a window of opportunity for the restoration of degraded arid ecosystems. Ecosystems 4: 151-159.

HOLMGREN M, M SCHEFFER, E EZCURRA, JR GUTIÉRREZ \& GMJ MOHREN (2001) El Niño effects on the dynamics of terrestrial ecosystems. Trends in Ecology and Evolution 16: 89-94

HOLMGREN M, P STAPP, CR DICKMAN, C GRACIA, S GRAHAM et al. (2006a) A synthesis of ENSO effects on drylands in Australia, North America and South America. Advances in Geosciences 6: 69-72.

HOLMGREN M, P STAPP, CR DICKMAN, C GRACIA, S GRAHAM et al. (2006b) Extreme climatic events shape arid and semiarid ecosystems. Frontiers in Ecology \& Environment 4: 87-95.

INOUYE RS (1991) Population biology of desert annual plants. In: Polis GA (ed) The ecology of desert communities: 27-54. University of Arizona Press, Tucson, AZ.
IPCC (2007) Impacts and vulnerability. Contribution of Working Group II to the Fourth Assesment. In: Parry ML, OF Canziani, JP Palutikof, PJ van der Linden, \& CE Hanson (eds) Report of the Intergovernmental Panel on Climatic Change. Cambridge University Press, Cambridge, UK.

IRIARTE JA, GA LOBOS \& FM JAKSIC (2005) Invasive vertebrate species in Chile and their control and monitoring by governmental agencies. Revista Chilena de Historia Natural 78: 143-154.

JAKSIC FM (1998a) Vertebrate invaders and their ecological impacts in Chile. Biodiversity Conservation 7: 1427-1445.

JAKSIC FM (1998b) Ecología de los vertebrados de Chile. Segunda edición. Ediciones Universidad Católica de Chile, Santiago, Chile.

JAKSIC FM (2001) Ecological effects of El Niño in terrestrial ecosystems of western South America. Ecography 24: 241-250.

JAKSIC FM, HW GREENE \& JL YÁÑEZ (1981) The guild structure of a community of predatory vertebrates in central Chile. Oecologia 49:21-28.

JAKSIC FM, JE JIMÉNEZ, SA CASTRO \& P FEINSINGER (1992) Numerical and functional response of predators to a long-term decline in mammalian prey at a semi-arid Neotropical site. Oecologia 89: 90-101.

JAKSIC FM \& I LAZO (1999) Response of a bird assemblage in semiarid Chile to the 1997-1998 El Niño. Wilson Bulletin 111: 527-535.

JAKSIC FM \& M LIMA (2003) Myths and facts on ratadas: Bamboo blooms, rainfall peaks and rodent outbreaks in South America. Austral Ecology 28: 237-251.

JAKSIC FM, PL MESERVE, JR GUTIÉRREZ \& E TABILO (1993) The components of predation on small mammals in semiarid Chile: Preliminary results. Revista Chilena de Historia Natural 66: 305-321.

JAKSIC FM, SI SILVA, PL MESERVE \& JR GUTIÉRREZ (1997) A long-term study of vertebrate predator responses to an El Niño (ENSO) disturbance in western South America. Oikos 78: 341-354.

JAKSIC FM, E SILVA-ARÁNGUIZ \& SI SILVA (2004) Fauna del Parque Nacional Bosque Fray Jorge: una revision bibliográfica. In: Squeo FA, JR Gutiérrez \& IR Hernández (eds) Historia natural del Parque Nacional Bosque Fray Jorge: 93-114. Ediciones Universidad de La Serena, La Serena, Chile.

JIMÉNEZ JE, P FEINSINGER \& FM JAKSIC (1992) Spatiotemporal patterns of an irruption and decline of small mammals in northcentral Chile. Journal of Mammalogy 73: 356-364.

KAREIVA P, JG KINGSOLVER \& RB HUEY (eds) (1992) Biotic interactions and global change. Sinauer Association, Sunderland, MA.

KARR JR (1992) Bottom-up versus top-down regulation of vertebrate populations: Lessons from birds and fish. In: Hunter MD, T Ohgushi \& PW Price (eds) Effects of resource distribution on animal-plant interactions: 244-286. Academic Press, San Diego, CA.

KELT DA, JH BROWN, EJ HESKE, PA MARQUET, SR MORTON, JRW REID, KA ROGOVIN \& G SHENBROT (1996) Community structure of desert small mammals: Comparisons across four continents. Ecology 77: 746-761.

KELT DA, PL MESERVE, KL NABORS, ML FORISTER \& JR GUTIERREZ (2004a) Foraging ecology of small mammals in semiarid Chile: 
The interplay of biotic and abiotic effects. Ecology 85: 383-397.

KELT DA, PL MESERVE, ML FORISTER, LK NABORS \& JR GUTIÉRREZ (2004b) Seed predation by birds and small mammals in semiarid Chile. Oikos 104: 131-141.

KELT DA, PL MESERVE \& JR GUTIÉRREZ (2004c) Seed removal by small mammals, birds, and ants in semi-arid Chile, and comparisons with other systems. Journal of Biogeography 31: 931-942.

KERLEY GIH \& WG WHITFORD (1994) Desertdwelling small mammals as granivores: Intercontinental variations. Australian Journal of Zoology 42: 543-555.

KERR RA (2004) A few good climate shifters. Science 306: 599-601.

KIRTMAN BP \& PS SCHOPF (1998) Decadal variability in ENSO predictability and prediction. Journal of Climate 11: 2804-2822.

KLEEMAN R \& SB POWER (2000) Modulation of ENSO variability on decadal and longer time scales. In: Diaz HF \& V Markgraf (eds) El Niño and the Southern Oscillation: Multiscale variability and global and regional impacts: 413441. Cambridge University Press, Cambridge, UK.

KOVATS RS, MJ BOUMA \& A HAINES (1999) El Niño and Health. World Health Organization, WHO/ SDE/PHE/99.4, Geneva, Switzerland.

KREBS CJ, S BOUTIN, R BOONSTRA, ARE SINCLAIR, JNM SMITH, MRT DALE, K MARTIN \& $R$ TURKINGTON (1995) Impact of food and predation on the snowshore hare cycle. Science 269: 1112-1115.

KRISTOFFERSEN AB，OC LINGJÆRDE, N CHR STENSETH \& M SHIMADA (2001) Nonparametric modelling of non-linear density dependence: A three-species host-parasitoid system. Journal of Animal Ecology 70: 808-819.

KUMMEROW J (1966) Contribución al conocimiento de las condiciones climáticas del bosque Fray Jorge. Boletín Técnico No. 24: 21-28, Facultad de Agronomía, Universidad de Chile, Santiago, Chile.

KUNST C, S BRAVO, F MOSCOVICH, J HERRERA, J GODOY \& S VELEZ (2003) Fecha de aplicación de fuego y diversidad de herbáceas en una sabana de Elionorus muticus (Spreng). O. Kuntze. Revista Chilena de Historia Natural 76: 105-115.

LAAKE JL, ST BUCKLAND, DR ANDERSON \& K P BURNHAM (1993) DISTANCE users guide. Version 2. Colorado Coop. Fish Wildlife Research Unit, Colorado State University, Fort Collins, $\mathrm{CO}$.

LAGOS VO (1993) Riesgo de predación y temperatura ambiental como determinantes del uso del espacio por Octodon degus: Un estudio de campo. M.S. Thesis, Universidad de Chile, Santiago, Chile.

LAGOS VO, LC CONTRERAS, PL MESERVE, JR GUTIÉRREZ \& FM JAKSIC (1995) Effects of predation risk on space use by small mammals: A field experiment with a Neotropical rodent. Oikos 74: 259-264.

LATIF M, D ANDERSON, T BARNETT, M CANE, R KLEEMAN et al. (1998) A review of the predictability and prediction of ENSO. Journal of Geophysic Research 103: 14375-14393.

LAZO A, C DE LE COURT \& RC SORIGUER (1992) Evaluation of hare abundance allowed by their use of attraction points. Z. Säugetierkunde 57: 373-379.

LEE ET (1980) Statistical methods for survival data analysis. Lifetime Learning Publications, Belmont, CA.

LEIRS H, NC STENSETH, JD NICHOLS, JE HINES, R VERHAGEN \& W VERHEYEN (1997) Stochastic seasonality and nonlinear density-dependent factors regulate population size in an African rodent. Nature 389: 176-180.

LETNIC M, B TAMAYO \& CR DICKMAN (2005) The responses of mammals to La Niña (ENSO) associated rainfall, predation and wildfire in arid Australia. Journal of Mammalogy 86: 689-703.

LETNIC M, CR DICKMAN, M TISCHLER, B TAMAYO \& C-L BEH (2004) The responses of small mammals and lizards to post-fire succession and rainfall in arid Australia. Journal of Arid Environments 59: 85-114

LEWELLEN R H \& SH VESSEY (1998) The effect of density dependence and weather on population size of a polyvoltine species: The importance of time scale. Ecological Monographs 68: 571-594.

LEVIN SA (1992) The problem of pattern and scale in ecology. Ecology 73: 1943-1967.

LIDICKER WZ JR (1991) In defense of a multifactor perspective in population ecology. Journal of Mammalogy 72: 631-635.

LIDICKER WZ JR (1995) The landscape concept: Something old, something new. In: Lidicker WZ (ed) Landscape approaches in mammalian ecology and conservation: 3-19. University of Minnesota Press, Minneapolis, MN.

LIKENS G (1989) Long-term studies in ecology. Springer-Verlag, New York.

LIMA M (2001) The dynamics of natural populations: Feedback structures in fluctuating environments. Revista Chilena de Historia Natural 74: 317-329.

LIMA M \& FM JAKSIC (1998a) Delayed densitydependent and rainfall effects on reproductive parameters of an irruptive rodent in semiarid Chile. Acta Theriologica 43: 225-236.

LIMA M \& FM JAKSIC (1998b) Population dynamics of three Neotropical small mammals: Time series models and the role of delayed densitydependence in population irruptions. Australian Journal of Ecology 24: 25-34.

LIMA M \& FM JAKSIC (1998c) Population variability among three small mammal species in the semiarid Neotropics: The role of densitydependent and density-independent factors. Ecography 21: 175-180.

LIMA M, JE KEYMER \& FM JAKSIC (1999a) El Niñosouthern-oscillation-driven rainfall variability and delayed density dependence cause rodent outbreaks in western South America: Linking demography and population dynamics. American Naturalist 153: 476-491.

LIMA M, PA MARQUET \& FM JAKSIC (1999b) El Niño events, precipitation patterns, and rodent outbreaks are statistically associated in semiarid Chile. Ecography 22: 213-218.

LIMA M, MR JULLIARD, N CHR STENSETH \& FM JAKSIC (2001a) Demographic dynamics of a neotropical small rodent (Phyllotis darwini): Feedback structure, predation and climatic factors. Journal of Animal Ecology 70: 761-775.

LIMA M, NC STENSETH, NG YOCCOZ \& FM JAKSIC (2001b) Demography and population dynamics 
of the mouse opossum (Thylamys elegans) in semi-arid Chile: Seasonality, feedback structure and climate. Proceedings of the Royal Society London B 268: 1-12.

LIMA M, NCHR STENSETH \& FM JAKSIC (2002a) Food web structure and climatic effects on the dynamics of small mammals and owls in semiarid Chile. Ecology Letters 5: 273-284.

LIMA M, NCHR STENSETH \& FM JAKSIC (2002b) The population dynamics of a South American small rodent: Seasonal structure interacting with the role of climate, density-dependence and predator guild effects. Proceedings of the Royal Society London B 269: 2579-2586.

LIMA M, MA PREVITALI \& PL MESERVE (2006) Climate and small rodent dynamics in semiarid Chile: The role of lateral and vertical perturbations and intra-specific processes. Climate Research 30: 125-132.

LOBOS G, M FERRES \& RE PALMA (2005) Presencia de los géneros invasores Mus y Rattus en área naturales de Chile: Un riesgo ambiental y epidemiológico. Revista Chilena de Historia Natural 78: 113-124.

LOEUILLE N \& M GHIL (2004) Intrinsic and climatic factors in North-American animal population dynamics. BMC Ecology 4: 6.

LOGAN JA, J RÉGNIÈRE \& JA POWELL (2003) Assessing the impacts of global warming on forest pest dynamics. Frontiers in Ecology \& Environment 1: 130-137.

LÓPEZ DE CASENAVE J, VR CUETO \& L MARONE (1998) Granivory in the Monte desert: Is it less intense than in other arid zones of the world? Global Ecology \& Biogeography Letters 7: 197-204.

LUBCHENCO J (1986) Relative importance of competition and predation: Early colonization by seaweeds in New England. En: Diamond J \& TJ Case (eds) Community ecology: 537-555. Harper \& Row, New York, NY.

MANN ME, RS BRADLEY \& MK HUGHES (2000) Long-term variability in the El Niño/Southern Oscillation and associated teleconnections. In: Diaz HF \& V Markgraf (eds) El Niño and the Southern Oscillation: Multiscale variability and global and regional impacts: 357-412. Cambridge University Press, Cambridge, UK.

MANRIQUE R, JR GUTIÉRREZ, M HOLMGREN \& FA SQUEO (2007) Reduced herbivory during simulated ENSO rainy events increases native herbaceous plants in semiarid Chile. Plant Ecology 191: 21-31.

MARES MA \& ML ROSENZWEIG (1978) Granivory in North and South American deserts: Rodents, birds, and ants. Ecology 59: 235-241.

MARONE L \& ME HORNO (1997) Seed reserves in the central Monte Desert, Argentina: Implications for granivory. Journal of Arid Environments 36: 661-670.

MARONE L, BE ROSSI \& J LÓPEZ DE CASENAVE (1998) Granivore impact on soil seed reserves in the central Monte Desert, Argentina. Functional Ecology 12: 640-645.

MARONE L, J LÓPEZ DE CASENAVE \& VR CUETO (2000) Granivory in southern South American deserts: Conceptual issues and current evidence. BioScience 50: 123-132.

MARTICORENA C \& M QUEZADA (1985) Catálogo de la flora vascular de Chile. Gayana Botánica 42: 1152.
MARTÍNEZ DEL RÍO C, A SILVA, M HOURDEQUIN \& RG MEDEL (1996) Seed dispersers as disease vectors: Bird transmission of mistletoe seeds to plant hosts. Ecology 77: 912-921.

MCCARTY JP (2001) Ecological consequences of recent climate change. Conservation Biology 15: 320-331.

MCQUEEN DJ, JR POST \& EJ MILLS (1986) Trophic relationships in freshwater pelagic ecosystems. Canadian Journal of Fisheries Aquatic Sciences 43: 1571-1581.

MCQUEEN DJ, MRS JOHANNES, JR POST, TJ STEWART \& DRS LEAN (1989) Bottom-up and top-down impacts on freshwater pelagic community structure. Ecological Monograph 59: 289-309.

MEDEL RG (1995) Convergence and historical effects in harvester ant assemblages of Australia, North America, and South America. Biological Journal of the Linnean Society 55: 29-44.

MEDEL RG \& RA VÁSQUEZ (1994) Comparative analysis of harvester ant assemblages of Argentinian and Chilean arid zones. Journal of Arid Environments 26: 363-371.

MENGE BA (1995) Indirect effects in marine rocky intertidal interaction webs: Patterns and importance. Ecological Monograph 65: 21-74.

MESERVE PL (1981a) Resource partitioning in a Chilean semi arid small mammal community. Journal of Animal Ecology 50: 745-757.

MESERVE PL (1981b) Trophic relationships among small mammals in a Chilean semiarid thorn scrub community. Journal of Mammalogy 62: 304-314.

MESERVE PL \& ER LE BOULENGÉ (1987) Population dynamics and ecology of small mammals in the northern Chilean semiarid region. In: Patterson BD \& RM Timm (eds) Studies in Neotropical mammalogy: Essays in honor of Philip Hershkovitz: 413-431. Fieldiana Zoology New Series 39.

MESERVE PL, RE MARTIN \& J RODRÍGUEZ (1983) Feeding ecology of two Chilean caviomorphs in a central mediterranean savanna. Journal of Mammalogy 64: 322-325.

MESERVE PL, RE MARTIN \& J RODRÍGUEZ (1984) Comparative ecology of the caviomorph rodent Octodon degus in two Chilean mediterranean-type communities. Revista Chilena de Historia Natural 57: 79-89.

MESERVE PL, EJ SHADRICK \& DA KELT (1987) Diets and selectivity of two Chilean predators in the northern semi-arid zone. Revista Chilena de Historia Natural 60: 93-99.

MESERVE PL, JR GUTIÉRREZ, LC CONTRERAS \& FM JAKSIC (1993a) Role of biotic interactions in a semiarid scrub community in north-central Chile: A long-term ecological experiment. Revista Chilena de Historia Natural 66: 225-241.

MESERVE PL, JR GUTIÉRREZ \& FM JAKSIC (1993b) Effects of vertebrate predation on a caviomorph rodent, the degu (Octodon degus), in a semiarid thorn scrub community in Chile. Oecologia 94: 153-158.

MESERVE PL, JA YUNGER, JR GUTIÉRREZ, LC CONTRERAS, WB MILSTEAD et al. (1995) Heterogeneous responses of small mammals to an El Niño Southern Oscillation in north-central semiarid Chile and the importance of ecological scale. Journal of Mammalogy 76: 580-595. 
MESERVE PL, JR GUTIÉRREZ, JA YUNGER, LC CONTRERAS \& FM JAKSIC (1996) Role of biotic interactions in a small mammal assemblage in semiarid Chile. Ecology 77: 133-148.

MESERVE PL, WB MILSTEAD, JR GUTIÉRREZ \& FM JAKSIC (1999) The interplay of biotic and abiotic factors in a semiarid Chilean mammal assemblage: Results of a long-term experiment. Oikos 85: 364-372.

MESERVE PL, WB MILSTEAD \& JR GUTIÉRREZ (2001) Results of a food addition experiment in a north-central Chile small mammal assemblage: Evidence for the role of «bottom-up» factors. Oikos 94: 548-556.

MESERVE PL, DA KELT, WB MILSTEAD \& JR GUTIÉRREZ (2003) Thirteen years of shifting top-down and bottom-up control. BioScience 53: 633-646.

MESERVE PL, DA KELT, WB MILSTEAD \& JR GUTIÉRREZ (2004) Una investigación de largo plazo de la interacción de factores bióticos y abióticos en el Parque Nacional Bosque Fray Jorge. In: Squeo FA, JR Gutiérrez \& IR Hernández (eds) Historia natural del Parque Nacional Bosque Fray Jorge, Región de Coquimbo, Chile: 135-159. Ediciones Universidad de La Serena, La Serena, Chile.

MESERVE PL, JR GUTIÉRREZ, DA KELT, MA PREVITALI, A ENGILIS JR \& WB MILSTEAD (2009) Global climate change and biotic-abiotic interactions in the northern Chilean semiarid zone: Potential long-term consequences of increased El Niños. In: Long JA \& DS Wells (eds) Ocean circulation and El Niño: New research: 139-162. Nova Press, NY.

MILLS LS, PC GRIFFIN, KE HODGES, K MCKELVEY, L RUGGIERO \& T ULIZIO (2005) Pellet count indices compared to mark-recapture estimates for evaluating snowshoe hare density. Journal of Wildlife Management 69: 1053-1062.

MILSTEAD WB (2000) The demographic and genetic structure of arid-land small mammal populations in north-central Chile: Rainfall, refuges and ratadas. Ph.D. Disertation, Northern Illinois University, DeKalb, IL.

MILSTEAD WB, PL MESERVE, A CAMPANELLA, MA PREVITALI, DA KELT \& JR GUTIÉRREZ (2007) Spatial ecology of small mammal populations in north-central Chile: Role of precipitation and refuges. Journal of Mammalogy 88: 1532-1538.

MINN AH (2002) Ecology of a reptile assemblage in a semiarid community in north-central Chile. M.S. Thesis, Northern Illinois University, DeKalb, IL.

MITTELBACH GG, CW OSENBERG \& MA LEIBOLD (1988) Trophic relations and ontogenetic niche shifts in aquatic ecosystems. In: Ebenman B \& L Persson (eds) Size-structured populations: 219235. Springer-Verlag, Berlin.

MORTON SR (1985) Granivory in arid regions: Comparison of Australia with North and South America. Ecology 66: 1859-1866.

MUÑOZ M (1985) Flores del Norte Chico. Dirección de Bibliotecas, Municipalidad de La Serena, La Serena, Chile.

MUÑOZ PC \& E PISANO (1947) Estudio de la vegetación y flora de los Parques Nacionales de Fray Jorge y Talinay. Agricultura Técnica (Chile) 2: 71-190.

MURRAY DL, JD ROTH, E ELLSWORTH, AJ WIRSING \& TD STEURY (2002) Estimating low-density snowshoe hare populations using fecal pellet counts. Canadian Journal of Zoology 80: 771-781.

MURRAY DL, E ELLSWORTH \& A ZACK (2005) Assessment of potential bias with snowshoe hare fecal pellet-plot counts. Journal of Wildlife Management 69: 385-395.

MURÚA R, LA GONZÁLEZ \& M LIMA (2003) Secondorder feedback and climatic effects determine the dynamics of a small rodent population in a temperate forest of South America. Oecologia 45: 19-24.

MYSTERUD A, NC STENSETH, NG YOCCOZ, R LANGVATN \& G STEINHEIM (2001) Nonlinear effects of large-scale climatic variability on wild and domestic herbivores. Nature 410: 1096-1099.

NICHOLSON AJ (1993) The balance of animal populations. Journal of Animal Ecology 2: 132-178.

OKSANEN L, SD FRETWELL, J ARRUDA \& P NIEMELÄ (1981) Exploitation ecosystems in gradients of primary productivity. American Naturalist 118: 240-261.

OKSANEN L \& T OKSANEN (2000) The logic and realism of the hypothesis of exploitation ecosystems. American Naturalist 155: 703-723.

OSENBERG CW, O SARNELLE \& SD COOPER (1997) Effect size in ecological experiments: The application of biological models in meta-analysis. American Naturalist 150: 798-812.

OSTFELD RS \& F KEESING (2000) Pulsed resources and community dynamics of consumers in terrestrial ecosystems. Trends in Ecology and Evolution 15: 232-237.

OSTFELD RS, CG JONES \& JO WOLFF (1996) Of mice and mast: Ecological connections in eastern deciduous forests. BioScience 46: 323-330.

OVALLE C, J ARONSON, J AVENDAÑO, R MENESES \& R MORENO (1993) Rehabilitation of degraded ecosystems in central Chile and its relevance to the arid "Norte Chico". Revista Chilena de Historia Natural 66: 291-303.

PALOMARES F (2001) Comparison of 3 methods to estimate rabbit abundance in a Mediterranean environment. Wildlife. Society Bulletin 29: 578-585.

PARKER JD, DE BURKEPILE \& ME HAY (2006) Opposing effects of native and exotic herbivores on plant invasions. Science 311: 1459-1461.

PARMESAN C (2006) Ecological and evolutionary responses to recent climatic change. Annual Review of Ecology \& Systematics 37: 637-669.

PEARSON OP (1975) An outbreak of mice in the coastal desert of Peru. Mammalia 39: 375-386.

PÉFAUR JE, JL YÁÑEZ \& FM JAKSIC (1979) Biological and environmental aspects of a mouse outbreak in the semi-arid region of Chile. Mammalia 43: 313-322

PETERS RL \& TE LOVEJOY (1992) Global warming and biological diversity. Yale University Press, New Haven, CT.

POLIS GA (1999) Why are parts of the world green: Multiple factors control productivity and the distribution of biomass. Oikos 86: 3-15.

POLIS GA, RD HOLT, BA MENGE \& KO WINEMILLER (1996) Time, space, and life history: Influences on food webs. In: Polis GA \& KO Winemiller (eds) Food webs: Integration of patterns and dynamics: 435-460. Chapman and Hall, New York, NY

POLIS GA, SD HURD, CT JACKSON \& F SÁNCHEZPIÑERO (1997) El Niño effects on the dynamics and control of an island ecosystem in the Gulf of California. Ecology 78: 1884-1897. 
POTVIN C, MJ LECHOWICZ \& S TARDIF (1990) The statistical analysis of ecophysiological response curves obtained from experiments involving repeated measures. Ecology 71: 1389-1400.

POWELL TM (1989) Physical and biological scales of variability in lakes, estuaries, and the coastal ocean. In: Roughgarden J, RM May \& SA Levin (eds) Perspectives in ecological theory: 157-176. Princeton University Press, Princeton, NJ.

PREVITALI MA (2006) Patterns and mechanisms of population dynamics of small mammals in semiarid Chile: The role of biotic and abiotic factors. Ph.D. Disertation, Northern Illinois University, DeKalb, IL.

PREVITALI MA, M LIMA, PL MESERVE, DA KELT \& JR GUTIERREZ (2009) Population dynamics of two sympatric rodent species in a highly variable environment: The influence of rainfall, resource availability, and predation. Ecology 90: 1996-2006.

PREVITALI MA, PL MESERVE, DA KELT, WB MILSTEAD \& JR GUTIÉRREZ (2010) Effects of more frequent and prolonged El Niño events on life-history parameters of Octodon degus, a longlived and slow-reproducing caviomorph rodent. Conservation Biology 24: 18-28.

PULLIAM HR (1988) Sources, sinks and population regulation. American Naturalist 132: 652-661.

RAJAGOPALAN B, U LALL \& MA CANE (1997) Anomalous ENSO occurrences: An alternative view. Journal of Climate 10: 2351-2357.

REED AW, GA KAUFMAN \& BK SANDERCOCK (2007) Demographic response of a grassland rodent to environmental variability. Journal of Mammalogy 88: 982-988.

REICH PB, BA HUNGATE \& Y LUO (2006) Carbonnitrogen interactions in terrestrial ecosystems in response to rising atmospheric carbon dioxide. Annual Review of Ecology, Evolution \& Systematic 37: 611-636.

RISSER PG (1991) Long-term ecological research: An international perspective. SCOPE, Vol. 47. ICSU, Wiley, New York.

RISSER PG, T ROSSWALL \& RG WOODMANSEE (1988) Spatial and temporal variability of biospheric and geospheric processes: A summary. In: Rosswall T, RG Woodmansee \& PG Risser (eds) Scales and global change: 1-10. Science Communication Prob. Environment (SCOPE), J. Wiley \& Sons, New York.

ROUGHGARDEN J \& J DIAMOND (1986) Overview: The role of species interactions in community ecology. In: Diamond J \& TJ Case (eds) Community ecology: 333-343. Harper \& Row, New York, NY.

ROYAMA T (1992) Analytical population dynamics. Chapman and Hall, London, UK.

SATHER B-E, J TUFTO, S ENGEN, K JERSTAD, OW ROSTAD \& JE SKATAN (2000) Population dynamical consequences of climate change for a small temperate songbird. Science 287: 854-856.

SAGE RD, OP PEARSON, J SANGUINETTI \& AK PEARSON (2007) Ratada 2001: A rodent outbreak following the flowering of bamboo (Chusquea culeou) in southwestern Argentina. In: Kelt DA, EP Lessa, J Salazar-Bravo \& JL Patton (eds) The quintessential naturalist: Honoring the life and legacy of Oliver P. Pearson: 177-224. University of California Publications in Zoology 134, Berkeley, CA.

SALVATORI V, G VAGLIO-LAURIN, PL MESERVE \& L BOITANI (1999) Spatial organization, activity, and social interactions of culpeo foxes in northcentral Chile. Journal of Mammalogy 80: 711-719.

SAS $^{\odot}$ INSTITUTE INC (1990a) SAS/STAT ${ }^{\odot}$ User's Guide, Version 6, Volume 1. Fourth edition. Cary, NC.

SAS $^{\odot}$ INSTITUTE INC (1990b) SAS/STAT ${ }^{\odot}$ User's Guide, Version 6, Volume 2. Fourth edition. Cary, NC.

SAS $^{\odot}$ INSTITUTE INC (1996) SAS/STAT ${ }^{\odot}$ Software. Changes and enhancements through release 6.11. Cary, NC.

SAX DF (2002) Native and naturalized plant diversity are positively correlated in scrub communities of California and Chile. Diversity \& Distributions 8: 193-210.

SCHOENER TW (1986) Mechanistic approaches to community ecology: A new reductionism? American Zoology 26: 81-106.

SCHMITZ OJ, PA HAMBÄCK \& AP BECKERMAN (2000) Trophic cascades in terrestrial systems: A review of the effects of carnivore removals on plants. American Naturalist 115: 141-153.

SCHNEIDER DC (2001) The rise of the concept of scale in ecology. BioScience 51: 545-553.

SCHNURR JL, RS OSTFELD \& CD CANHAM (2001) Direct and indirect effects of masting on rodent populations and tree seed survival. Oikos 96: 402-410.

SCHOFIELD CJ \& EH BUCHER (1986) Industrial contribution to desertification in South America. Trends in Ecology and Evolution 1: 78-80.

SILVA SI, I LAZO, E SILVA-ARÁNGUIZ, FM JAKSIC, PL MESERVE \& JR GUTIÉRREZ (1995) Numerical and functional response of burrowing owls to long-term mammal fluctuations in Chile. Journal of Raptor Research 29: 250-255.

SINCLAIR ARE (1989) Population regulation of animals. In: Cherrett JM (ed) Ecological concepts: 197-241. Blackwell Scientific Publications, London, UK.

SOKAL RR \& FJ ROHLF (1981) Biometry. Second edition WH Freeman and Company, San Francisco, California, USA.

SQUEO FA, JR GUTIÉRREZ \& IR HERNÁNDEZ (2004) Historia natural del Parque Nacional Bosque Fray Jorge. Ediciones Universidad de La Serena, La Serena, Chile.

SQUEO FA, Y TRACOL, D LÓPEZ, JR GUTIÉRREZ, AM CÓRDOVA \& JR EHLERINGER (2006) ENSO effects on primary productivity in southern Atacama desert. Advances in Geosciences 6: 273-277.

S-PLUS (2000) Guide to statistics, Volume 1. Data Analysis Products Division, MathSoft, Seattle, WA.

STAPP P \& GA POLIS (2003) Influence of pulsed resources and marine subsidies on insular rodent populations. Oikos 102: 111-123.

STENSETH NCHR (1999) Population cycles in voles and lemmings: Density-dependence and phase dependence in a stochastic world. Oikos 87: 427461.

STENSETH NCHR, W FALCK, ON BJØRNSTAD \& CJ KREBS (1997) Population regulation in snowshoe hare and Canadian lynx: Asymmetric food web configurations between hare and lynx. Proceedings of the National Academy of Sciences USA 94: 5147-5152.

STENSETH NCHR, A MYSTERUD, G OTTERSEN, JW HURRELL, K-S CHAN \& M LIMA (2002) Ecological effects of climate fluctuations. Science 297: 1292-1296. 
STENSETH NCHR, G OTTERSEN, JW HURRELL, A MYSTERUD, M LIMA, K-S CHAN, NG YOCCOZ \& B ÅDLANDSVIK (2003) Studying climate effects on ecology through the use of climate indices: The North Atlantic Oscillation, El Niño Southern Oscillation and beyond. Proceedings of the Royal Society London B 270: 2087-2096.

STENSETH NCHR, K-S CHAN, G TAVECCHIA, T COULSON, A MYSTERUD, TH CLUTTONBROCK \& B GRENFELL (2004) Modelling nonadditive and nonlinear signals from climatic noise in ecological time-series: Soay sheep as an example. Proceedings of the Royal Society London, Series B 271: 1985-1993

STRAUSS SY (1991) Indirect effects in community ecology: Their definition, study and importance. Trends in Ecology and Evolution 6: 206-210.

TAITT MJ \& CJ KREBS (1983) Predation, cover, and food manipulations during a spring decline of Microtus townsendii. Journal of Animal Ecology 52: 837-848.

THOMAS L, JL LAAKE, S STRINDBERG, FFC MARQUES, ST BUCKLAND et al. (2006) Distance 5.0. Release 2. Research Unit for Wildlife Population Assessment, University of Saint Andrews, UK. URL: http://www.ruwpa.stand.ac.uk/distance/.

TIMMERMANN A, J OBERHUBER, A BACHER, M ESCH, M LATIF \& E ROECKNER (1999) Increased $\mathrm{El}$ Niño frequency in a climate model forced by future greenhouse warming. Nature 398: 694-697.

TORRES-CONTRERAS H \& F BOZINOVIC (1997) Food selection in an herbivorous rodent: Balancing nutrition and thermoregulation. Ecology 78: 2230-2237.

TURCHIN P (1995) Population regulation: Old arguments and a new synthesis. En: Capuccino N \& PW Price (eds) Population dynamics: New approaches and synthesis: 19-40. Academic Press, San Diego, CA.

TURCHIN P (2003) Complex population dynamics: A theoretical/empirical synthesis. Princeton University Press, Princeton, NJ.

TURCHIN P \& GO BATZLI (2001) Availability of food and the population dynamics of arvicoline rodents. Ecology 82: 1521-1534.

VALONE TJ \& JH BROWN (1996) Desert rodents: Long-term responses to natural changes and experimental manipulations. In: Cody ML \& JA Smallwood (eds) Long-term studies of vertebrate communities: 555-583. Academic Press, New York, NY.

VÁSQUEZ RA, RO BUSTAMANTE \& JA SIMONETTI (1995) Granivory in the Chilean matorral: Extending the information on arid zones of South America. Ecography 18: 403-409.

VELOSO C \& F BOZINOVIC (1993) Dietary and digestive constraints on basal energy metabolism in a small herbivorous rodent. Ecology 74: 2003-2010.

VELOSO C \& F BOZINOVIC (2000) Effect of food quality on the energetics of reproduction in a precocial rodent, Octodon degus. Journal of Mammalogy 81: 971-978.

VIDIELLA PE, JJ ARMESTO \& JR GUTIÉRREZ (1999) Vegetation change and sequential flowering after rain in the southern Atacama desert. Journal of Arid Environments 43: 449-458.

VILLALBA R (1994) Climatic fluctuations in mid-latitudes of South America during the last 1,000 years: Their relationships to the Southern Oscillation. Revista Chilena de Historia Natural 67: 453-461.

VON ENDE CN (2001) Repeated measures analysis: Growth and other time-dependent measures. In: Scheiner SM \& J Gurevitch (eds) Design and analysis of ecological experiments: 134-157. Second edition, Oxford University Press, New York, NY.

VUCETICH JA \& RO PETERSON (2004) The influence of top-down, bottom-up and abiotic factors on the moose (Alces alces) population of Isle Royale. Proceedings of the Royal Society London B 271: 183-189.

WALTHER GR, E POST, P CONVEY, A MENZEL, C PARMESAN et al. (2002) Ecological responses to recent climate change. Nature 416: 389-395.

WALTHER GR, L HUGHES, P VITOUSEK \& NCHR STENSETH (2005) Consensus on climate change. Trends in Ecology and Evolution 20: 648-649.

WARA MW, A RAVELO, AC \& ML DELANEY (2005) Permanent El Niño-like conditions during the Pliocene warm period. Science 309: 758-761.

WATKINSON AR \& WJ SUTHERLAND (1995) Sources, sinks, and pseudo-sinks. Journal of Animal Ecology 64: 126-130.

WESSMAN CA (1992) Spatial scales and global changes: Bridging the gap from plots to GCM grid cells. Annual Review of Ecology \& Systematics 23: 175-200.

WIENS JA (1989) Spatial scaling in ecology. Functional Ecology 3: 385-397.

WIENS JA, JF ADDICOTT, TJ CASE \& J DIAMOND (1986) Overview: The importance of spatial and temporal scale in ecological investigations. In: Diamond J \& TJ Case (eds) Community ecology: 145-153. Harper \& Row, New York, NY.

WHITE GC \& KP BURNHAM (1999) Program MARK: Survival estimation from populations of marked animals. Bird Studies 46 (supplement): 120-139.

WHITFORD WG (1993) Animal feedbacks in desertification: An overview. Revista Chilena de Historia Natural 66:243-251.WIENS JA (1986) Spatial scale and temporal variation in studies of shrub steppe birds. In: Diamond J \& TJ Case (eds) Community ecology: 154-172. Harper \& Row, NY.

WOLFINGER R \& M CHANG (1995) Comparing the SAS $^{\odot}$ GLM and Mixed Procedures for Repeated Measures. SUGI Proceedings 1995: 1-11.

WOODMANSEE RG (1988) Ecosystem processes and global change. In: Rosswall T, RG Woodmansee \& PG Risser (eds) Scales and global change: 1127. John Wiley \& Sons, New York, NY.

YUNGER JA, PL MESERVE \& JR GUTIÉRREZ (2002) Small mammal foraging behavior: Mechanisms for coexistence and implication for population dynamics. Ecological Monographs 72: 561-577.

YUNGER JA, PL MESERVE \& JR GUTIÉRREZ (2007) Effects of biotic interactions on spatial behavior of small mammals in a semiarid community in north-central Chile. In: Kelt DA, EP Lessa, J Salazar-Bravo \& JL Patton (eds) Festschrift in honor of Oliver P. Pearson: 141-164. University of California Publications in Zoology 134. Berkeley, CA. 